\title{
Postmodernizm ve Tanrı'nın Ölümü: Öznenin Arkeolojisi üzerine Bir Deneme
}

\section{Abdüllatif TüzER*}

\section{Postmodernism and The Death of God: \\ A Treatise on the Archeology of Subject}

Citation/C: Tüzer, Abdüllatif, (2015). Postmodernism and The Death of God: A Treatise on the Archeology of Subject, Milel ve Nihal, 12 (2), 73-124.

Abstract: Postmodernism is a settling accounts with modernism in the cause of diversity and freedom. Though modernist discourse was initially based on freedom and autonomy or self-government, it has eventually created a power that established dominance over individuals and did not allow of different subjectiveness. Behind the elimination of diversities and the loss of freedom lies the power and hegemony of Modern Subject. With the dismission of God, modern subject has got its power by acceding to the God's throne, and thereafter science and rational thinking was substitued for religion. But, as a result of the destruction of God by Nietzsche in La Gaya Scienza, modern subject has lost the ground and legitimacy of its existence, and it has been consequently dissolved into a plurality of nihilistic worlds that can be repeatedly created through unending different interpretations. The influence of Nietzsche's views on postmodernist thinkers is so great that they, just as Nietzsche, tend to stay away from both science and religon for the sake of diversity and freedom. And postmodernist thought naturally abominate God who has a transcendental being and a formative and absolute authority over individual, society and history. That is why postmodernism has inclined to a genuine atheism or a religion with no God.

* Doç. Dr., Muş Alparslan Üniversitesi, Fen-Edebiyat Fakültesi, Felsefe Bölümü [atuzer@hotmail.com] 
Key Words: postmodernism, god, religion, freedom, diversity.

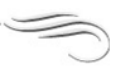

Atıf/C: Tüzer, Abdüllatif, (2015). Postmodernizm ve Tanrı'nın Ölümü: Öznenin Arkeolojisi Üzerine Bir Deneme, Milel ve Nihal, 12 (2), 73-124.

Öz: Postmodernizm, farklılık ve özgürlük adına modernizmle bir hesaplaşmadır. Her ne kadar modernist söylem özgürleşme ve özerklik üzerine inşa edilmiş olsa da, zamanla bireyler üzerinde tahakküm kuran ve farklı öznelliklere izin vermeyen bir iktidar yaratmaktan kendisini kurtaramamıştır. Farklılıkların silinmesinin ve özgürlük yitiminin baş sorumlusu ise modern öznedir. Modern özne bu gücü, önce Tanrıyı işinden ederek ve dünyadan kovarak ve sonra da Onun tahtına oturarak elde etmiş ve dinin yerine de bilimi ve rasyonel düşünceyi ikame etmiştir. Ne var ki, Nietzsche'nin Tanrının ölümünü ilan edişiyle birlikte muktedir modern özne de varlığının temelini ve meşruiyetini kaybetmiş ve sonsuzca yorumlarla sürekli yaratılan bir dünyalar çokluğunun içinde erimiş gitmiştir. Büyük ölçüde $\mathrm{Ni}$ etzsche'den ilham alarak beslenen postmodernist düşünce ise, farklılıkların ve özgürlüklerin yeşertilmesi adına, tıpkı Nietzsche gibi, bilime de dine de mesafeli durmuştur. Ve postmodernist düşüncenin, aşkın bir varlığa sahip olan ve insana, topluma, dünyaya ve tarihe biçim veren bir Tanrıya artık tahammülü yoktur. Tam da bu nedenle, postmodernizm, sahici bir ateizmdir.

Anahtar Kelimeler: postmodernizm, tanrı, din, özgürlük, farklılık.

Güçlü gücünü hakka ve kulluğu ödeve dönüştüremediği sürece efendiliğini sürekli kılamaz. ... Gücün her çeşidi Tanrı'dan kaynaklanır, kabul ediyorum; ama her illet de yine ondan gelir [Rousseau, Toplum Sözleşmesi: 35]

\section{Giriş}

Tarihin sonu, toplumsallı̆̆ın sonu, epistemolojinin sonu, bilimin sonu, öznenin sonu, gerçeğin sonu, teorinin sonu . . . Bugünlerde böylesi bir "son" retoriği ve söylemiyle sık karşılaşır olduk. Bu konuda kendisinden çok şey umulan, bu son retoriğine, kendisinin doğal karakteri olduğu sanılan kesinlik, hakikat, nesnellik, evrensellik, zorunluluk kılıcıyla son verip eski düzeni ve güveni sağlaması beklenen - ama hala layıkıyla anlaşılamamış olan - felsefenin de sonu getirildi. Özgürlük adına, özerklik adına, doğadaki, insandaki ve toplumsal olaylardaki bilinemez, belirsiz güçleri kontrol altına alabilmeye ve onu dilediğince kullanmaya muktedir bilim adına, despot ve muktedir bir kral Tanrının tahtından indirilmesiyle edinilmiş insan değeri ve hakları adına, gelecekteki demokratik cennetimiz adına sıkıca sarıldığımız ve korumak için canla başla mücadele verdiğimiz Aydınlanmacılığımız ve Modernistliğimizin kökleri sökülüyor, başı eziliyor, ruhu paramparça ediliyor. Modernizme 
düşman kesilen ve onu ayakta tutan bütün direkleri güçlü argümanlarla yerle bir etmeye ve onun zaaflarını, yetersizliklerini, kirli yüzünü, çelişkilerini, mahrem gizlerini ortaya dökmeye soyunan postmodernistlere verebildiğimiz tepkisel ve önyargılı cevap sadece şu oldu: Son moda saçmalıklar. Saçma olmalıydı belki de, çünkü postmodernizm, aydınlanmacı ve modernist söylemin sağladığı ayrıcalık, üstünlük, iktidar ve disipline ve böyle bir söylemden nemalananlara meydan okuyordu. Nitekim postmodernizme sarılan ve onu bir şifa gibi Türk entelektüellerin ve okur-yazarların yemek masasına sunanların, aydınlanmacı ve modernist söylemin ötekileştirdikleri, yabancılaştırdıkları ve değersizleştirdikleri - bilhassa muhafazakar ve dindarların - olması bu açıdan oldukça manidardır. Ne var ki malzemesine, yapılışına ve tadına bakmadan ilk bakışta cezbedici görünen farklılık, özgürlük, yerellik, kabilecilik, çoğulculuk baharatlı postmodernizmi sıcak ve lezzetli bir yemek gibi sunan muhafazakarlarımız ve dindarlarımız, sundukları yemekten aldıkları her bir lokmayla dişlerinin kırılacaklarının ve her bir kaşıkla zehirleneceklerinin farkında değillerdi. Çünkü nasıl ki postmodernizm, dinin tahtına oturan Aydınlanmacı felsefenin ve bunun toplumsal uzantısı Modernizmin düşmanı ise doğal olarak vahye dayalı geleneksel dinin de düşmanı olacaktır.

\section{Modernizm ve Tanrının Tahtına Oturan Özne}

Modernlik söylemi, Peter Wagner'in tabiriyle, esas olarak "özgürlük ve özerklik düşüncesine dayanır." ${ }^{1}$ Özerklik ise insanın kendi kaderi üzerindeki ilk ve son söz sahibinin kendisi olduğunu, onun kimliği, eylemleri, toplumsal tasarı ve icraatlarına ilişkin herhangi bir dışsal, üstün varlığın veya ilkenin hiçbir kural, ölçüt ya da kısıtlama koyamayacağını ifade eder. Modernlik projesinin esasını teşkil eden özgürlük ve özerklik fikri, kökleri aslında felsefe tarihinin en eski filozoflarına kadar uzansa da, varlığını önemli ölçüde Aydınlanma felsefesine borçludur. Gerilerden başlayacak olursak, Herakleitos'ta bütün değişimin gerisindeki ölçü ve değişmez yasa, farklılıklardaki bir ve ortak olan şey (Logos), Platon'da ölümsüz ve kusursuz akliyla maddeye şekil vererek kaostan kozmosu yaratan, Aristoteles'te bütün hareketliliğin gerisindeki kendisi hareket etmeyen ilk hareket ettirici; Tanrıdır. Temelsizliğin (nedenlerin, anlamın,

1 Peter Wagner, Modernliğin Sosyolojisi, çev. Mehmet Küçük, Ayrıntı Yayınları, İstanbul 2005, s. 27 
ilkelerin, tanımların nihai bir temelinin olmaması ve teselsül), anlamsızlığın, belirsizliğin, güvensizliğin, kaosun yarattığı şaşkınlık, dehşet, emniyetsizlik ve korkuya zihnin felsefe yoluyla (çünkü empirik bir temelden hareketle zihin buna bir cevap veremez, verebileceği cevap ancak mantıksal hassasiyete sahip bir kurgusal akla ait olabilirdi) verdiği ilk ve doğal tepki - belki doğal da olmayabilir çünkü geçmişe dönük kazılar gerçekleştiren düşünce tarihimiz, felsefenin dinden beslendiği, dinin üvey çocuğu olduğu kanısını güçlendiriyor - kendisi değişmeyen, her şeyin temeli ve zemini olmakla birlikte kendisinin bir temeli ve nedeni olmayan, sonlu ve değişene ait hiçbir leke ve kusur barındırmayan, her şeyi ihtiva edip her şeyi açıklayabilen, ezeli ve ebedi varlık fikri olmuştur. $\mathrm{Bu}$, tanımı itibariyle bildiğimiz, inandığımız Tanrıdan başkası değildir. Bu Tanrı'nın en önemli özelliği, düzenin gerisindeki değişmez, zorunlu, evrensel ve tek özgür temel/neden olması itibariyle, keyfilikten, duygusallıktan, kaprislilikten uzak olmasıydı. Wittgenstein'ın dediği gibi "Bir zamanlar, Tanrının her şeyi yaratabileceği, ama yalnızca mantık yasalarına aykırı bir şeyi yaratamayacağı söylenirdi. Çünkü 'mantıksız' bir dünyanın neye benzediğini söyleyemeyiz."2 Duygusal ve kaprisli bir Tanrının yaratacağı evren muhtemelen kaotik, düzensiz, öngörülemez, emniyetsiz olurdu. Oysa Tanrı duygusallıktan uzaktır ve bu yüzden $\mathrm{O}$, zorunlu, mantıksal ve matematiksel, evrensel bir doğaya sahip, kendi kendini akleden Saf Akıldır. Kısacası, zorunlu olması hasebiyle kendi kendinin nedeni olan ancak kendisinin dışındaki olumsal her şeyin temelini ve zeminini oluşturan -mümkün varlıkların ya da dünyanın temeli ve zemini olan Zorunlu Varlık - Tanrı, akıldır ya da tersten söyleyecek olursak, akıl Tanrıdır. Ya da Akıl ve Tanrı özdeştir. Öyle anlaşılıyor ki, akıl kavramı bütün anlamını Tanrıya borçludur.

Peki, insanın Tanrısal tasarım ve yaratımdaki yeri nedir? Yine felsefi düşüncenin izlerini takip edecek olursak açıkça görürüz ki insan varlık hiyerarşisinde üstün ve merkezi bir yere sahiptir. Adını zikrettiğimiz Herakletios, Platon ve Aristoteles için olduğu gibi bu çizgiyi takip eden Descartes, Spinoza, Leibniz gibi akılcılar için de

2 Ludwig Wittgenstein, Tractatus Logico-Philosophicus, çev. Oruç Aruoba, YKY, İstanbul 2001, s. 25 

insanın değeri Tanrısallığından, Tanrıdan bir parça taşıyor oluşundan gelir. ${ }^{3}$ Yoksa insanların en bilgesi, Herakleitos'un sözleriyle, Tanrıya kıyasla ancak bir maymundur. ${ }^{4}$ Insanın Tanrısallığı ise ölümsüz ruhunda bulunur ki ruhun da özniteliği akletmektir. Ne var ki insanoğlu yaratılışı gereği salt bir akıl varlığı değildir - çünkü salt akıl varlığı olan Tanrıdır ve $O$ kendinde, değişmeden ve çürümeden varlığını sürdüremeyen maddi hiçbir şey ihtiva etmez. Karışımında, paradoksal bir biçimde, madde vardır. Maddi tabiatı ise nefsani arzular, iştah, şehvet, öfke gibi irrasyonel duygular yoluyla - ruhun kanatlarında ağırlık yaparak onu yukarılara (cennete) gitmekten alıkoymakta, akılla kontrol edilemediği takdirde çürüyen, bozulan, karanlık, dilsiz ve katı madde çöplüğüne/cehenneme çekmektedir. Bu durumda insanın yeryüzündeki varlık sebebi ve imtihanı, nefsani tabiatı akılla dizginleyerek, tıpkı Tanrının maddeye şekil vermesi gibi insanın da Tanrısal aklıyla kendi maddesine şekil vererek Tanrıya benzemeye çalışmasıdır. Tanrıya benzeme fikri, daha önce adını zikrettiğimiz akılı filozofların ittifakla benimsediği bir idealdir. Dolayısıyla insanın en yüksek mutluluğu ve kurtuluşu, aklın duyguları kontrol altında tutarak ölçülü bir hayat sürmesinde ve en nihayet bilgi ve erdemle pişmiş ruhun ölümle maddeden tamamen kurtularak kaynağına, yani Tanrıya geri dönmesindedir. Sokrates' in ölüme giderken bir an bile tereddüt etmemesi, dünyanın ayartmalarına kanmaması bu yüzdendir.

Bu durumda insan paradoksal bir varlığa, çelişkili bir doğaya sahiptir. O, Tanrısal akla sahip olması itibariyle - felsefe ve dinin ortak diliyle, Tanrı insanı Kendi suretinde yaratmıştır, insana Kendi ruhundan üflemiştir - ölümsüzdür, sonsuzdur ancak cismani tabiatıyla sonludur, sınırlıdır; akıl varlığı olması itibariyle Tanrı gibi zorunlu, nesnel, evrensel ve kesin bilginin taşıyıcısıdır ve Tanrı gibi kendi içsel ilkelerinden hareketle kendini düşünebilme ve yönetebilme kudretine sahiptir ve özgürdür (özgürdür çünkü dışsal bir fail ya da ilkeye göre değil de kendi zorunlu doğasına göre hareket etme yeteneğine sahiptir) ancak maddi doğası itibariyle değişken, karar-

3 Aristoteles, Felsefeye Çağrı: Protreptikos, çev. S. Ö. Akkaş, Doruk Yayınları, Ankara 1999, s. 22; Platon, Theaitetos, çev. M. Gökberk, MEB Yayınları, İstanbul 1997, s. 91; G. W. Leibniz, Monadoloji, çev. Suut K. Yetkin, MEB Yayınları, İstanbul 1997, s. 19 ve Metafizik Üzerine Konuşma, çev. A. Timuçin, Cumhuriyet Dünya Klasikleri, Ankara 1999, s. 83; B. Spinoza, Törebilim, çev. A. Yardımlı, İdea Yayınları, İstanbul 2000, s. 42, 43, 69.

4 Herakletios, Kırık Taşlar, çev. Alova, Bordo-Siyah Yayınları, İstanbul 2003, s. 96 
sız, güvenilmez duyguların, arzuların esiridir. Kısacası insan, duygularına veya harici olumsal karakterdeki ilke ve faillere göre değil de aklına göre hareket ettiği takdirde, tıpkı Tanrı gibi kendi kendini belirleme, kendi kendinin nedeni olma kudretine, yani özgürlüğe ve özerkliğe sahiptir. Bu özgürlügü ona bahşeden Tanrıdır. Ancak Tanrı aynı zamanda bütün varlıkların zorunlu ve ortak nedeni olduğu için, bir başka ifadeyle, varlıkların özünü ve ereğini belirleyen İlk Neden olduğu için insan tamamen de özgür değildir. Yani, insan hem özgürdür hem özgür değildir. Oysa Tanrı, Spinoza'nın diliyle, kendi varlığının nedeni olan, var olmak için başka bir şeye muhtaç olmayan, varoluşu kendi doğasına özgü olan ve kendisi vasıtasıyla kavranan ve zorunlu, bölünemez ve sonsuz bir varoluşa sahip olan, salt kendi doğasının zorunluluğundan var olan ve yine salt özgür neden olan tek varlıktır. ${ }^{5}$ İnsan hem Tanrıdır hem Tanrı değildir. İnsanın bu paradoksallıktan, bu çelişkili durumdan kurtulabilmesi, kendi kaderini tayin hakkını tamamen kendi üzerine alabilmesi, salt özgür neden olabilmesi için radikal bir adım atması gerekiyordu. ${ }^{6}$

Sözünü ettiğimiz radikal adım, ilk planda, ya ilahi irade ve ereklilik fikrininin geçersizliğini dile getirerek ve evren ile Tanrı arasındaki döşenmiş bütün yolları tarumar ederek, bütün köprüleri yıkarak evrenin idaresini Tanrının elinden almak, Tanrıyı işinden etmek, Onu emekliye ayırmak, Onu kendi sessiz sonsuzluğuna uğurlamak olmuştur. Bundan böyle Tanrı evreni ne bilebilir, ne duyabilir, ne de ona müdahale edebilir - Bu görüş, deizm olarak anılıyor. Artık O, atıldır. Tanrıya ait bütün işleri bundan böyle kudretli ve özgür insanoğlu Tanrıdan devralmıştır ve bunun için de bilimi yaratmıştır. Bacon'ın dilinde insanoğlu bilim yoluyla doğanın hakimi konumuna yükselmiş, Kant'ın dilinde ise doğrunun ve iyinin nihai belirleyicisi olmuştur. Ya da ilk planda radikal adım, evrenTanrı dualitesini yıkıp Tanrı ile evreni özdeş kılan, her şeyin Tanrılığını dile getiren Spinoza'nın panteizmiyle insanın bütünüyle Tanrılaşması olmuştur. İkinci planda atılacak adım bellidir. Bir kez bütün ipleri eline aldıktan sonra Tanrıya ihtiyacı kalmayan insan ya Tanrı fikrini arkaik ve çocuksu bularak bir kenara atacak ve inancı hamlıkla niteleyecek ya da Feurbach, Freud, Sartre, Durkheim gibi düşünürlerin yol göstericiliğiyle Tanrıyı bir yanılsama, bir yanılgı,

B. Spinoza, Törebilim, s. 1-9.

6 Terry Eagleton, Kuramdan Sonra, çev. Uygar Abacı, Literatür Yayınları, İstanbul 2006, s. $198-201$. 
bir yansitma olarak görecek ve Tanrısallı̆̆ tamamen doğal nedenlere indirgeyecektir. Her şeyi maddeye indirgeyen materyalizm, bilimsel olarak doğrulanamayan şeylerin anlamsızlığında ve "Tanrı vardır" önermesinin mantıksal saçmalığında direten mantıkçı pozitivizm, doğal seçilim fikriyle ilahi amaçlılığı ve tesadüfi oluşla da Tanrının yaratıcılı̆̆ını ortadan kaldıran Darwinizm, sömürülenlerin isyan etmemesi ve teselliyi öte dünyada ve görünmez ama kudretli bir varlığın adaletinde bulmaları için dini yapay bir biçimde inşa eden, bir afyon üreten burjuva fikriyle Marksizm. Ve nihayet Tanrıyı öldürme vakti gelmiştir.

İnsanoğlu Tanrıyı öldürmüş ve Onun tahtına oturmuş olsa da Onun bıraktığı boşluğu doldurabilecek büyüklüğe, yaratıcılığa, kusursuzluğa, sonsuzluğa ve cesarete sahip değildir. Nihayetinde insanoğlu Tanrıyı öldürmüş olsa bile Onun tasarımı ve yaratımı olan dünyayı, yani ilahi krallığı Tanrıyla birlikte yerle bir etmiş ve cesur, yeni bir dünya yaratmış değildir. Tanrı ölse de kurmuş olduğu krallık ayaktadır ve bu krallığı ayakta tutacak güç, kural ve yöntemler bellidir. İnsanın yapabileceği tek şey, Tanrının stratejilerini izleyerek, kurallarını uygulayarak, aletlerini kullanarak, açtığı yollardan geçerek Onun boşluğunu doldurmaya çalışmak, Tanrı gibi olabilmek ve Tanrıyı oynamaktır.7 Kralı tahtan indiren insanoğlu bundan böyle tamamen özgür ve özerktir. Ancak Tanrıyı oynayabilmesi için eksik olan bazı şeyler vardır ve bu eksikliklerin ivedilikle giderilmesi elzemdir.

En önemli eksiklik, insanın Tanrı gibi salt tinsel, zaman ve mekan dışı, tarih üstü bir varlık olamamasıdır. İnsan aynı zamanda bir arzu ve duygu varlığıdır, kanlı canlıdır, değişim ve çürümeden azade değildir, belli bir tarihin ve geleneğin çocuğudur. Dolayısıyla insanın Tanrıyı oynayabilmesi için bedeninden, arzu ve duygularından, tarihsellikten, zaman ve mekandan soyutlanması gerekiyordu. Çünkü bütün bunlar onun kendi kendine yeterliğini zedeliyor, kendinin nedeni olma idealini yıkıyor, doğaya ve topluma hükmetme gücü verecek, birliği tesis edebilecek ve böylelikle ona her şeyin temeli olma imkanını sağlayacak mutlaklık, zorunluluk, nesnellik, kesinlik ve evrensellik gibi silahları elinden alıyordu. Bu yüzden

Tanrıyı oynama fikri için bkz. M. Horkheimer ve Theodor W. Adorno, Aydınlanmanın Diyalektiği I, çev. Oğuz Özügül, Kabalcı Yayınları, İstanbul 1995, s. 25; M. Horkheimer, Akıl Tutulması, çev. Orhan Koçak, Metis Yayınları, İstanbul 1994, s. $62 \mathrm{vd}$. 
insanın, Tanrının yerini almaya layık evrensel karakterde, kendi başına ayakta durabilen, kendi kendinin nedeni ve belirleyicisi olan, aynı zamanda duygulardan, tarihsellikten ari, tüm bu özellikleri itibariyle de her şeyin nihai temelini ve zemini oluşturabilecek kapasiteye sahip soyut bir "özne" yaratması gerekiyordu. Dikkat edilirse, "özne"nin İngilizce karşıllğ 1 "subject" altta yatan, temel olan anlamına gelmektedir. Bu soyut özne, hiçbir zaman ekonomik, toplumsal, etnik, cinsel, kültürel, siyasal veya dinsel aidiyeti ile tanımlanmaz çünkü o, bütün bunların önündedir ve bunlardan önce gelir. Bu haliyle özne, kendisi temelsiz olmakla birlikte her şeyin temeli olan etsiz-kemiksiz bir varlık, atomize olmuş ve yükümsüz, bütünüyle ruhsal/hayali bir varlık gibidir.8 Ve tabi ki bu varlık, Tanrıdan miras kalan akılsallığı itibariyle de ekonomiye, topluma, tarihe, siyasete, dine vs. ayar ve düzen verebilecek evrensellik, zorunluluk, kesinlik, mutlaklık, nesnellik kılıcına da sahiptir. Bundan böyle, olumsal karaktere sahip doğa, toplum, tarih, siyaset üzerinde aklın ezeli-ebedi doğruları, evrensel yasaları hükmünü sürecektir.

Aslında bu modern özne anlayışına giden yollar, her birisinin felsefesinin ana direğini Tanrı oluşturuyor olsa da, Descartes, Leibniz, Spinoza ve Kant tarafından döşenmiştir. Kesin bilginin imkanını ve nihai temelini sorgulayan Descartes “Düşünüyorum öyleyse varım"la tüm bilginin üzerine inşa edileceği sağlam, evrensel bir temel ve kurucu rolündeki özne fikrini geliştirmişti. Öyle bir özne ki, bu, var olmak için kendinden başka bir nedene ihtiyaç duymayan, yani kendi başına var olan ve ayakta duran, özniteliği esas itibariyle düşünmek olan ölümsüz, - bileşik olmayan anlamında- basit ruhsal bir tözdür. Ancak bu tözün, kendinden bağımsız evrenin kesin bir bilgisini edinebilmesi, bilim yapabilmesi için, doğuştan en yetkin varlık fikrini (Tanrıyı) taşıyor olması ve bu fikrin de algıda ve düşüncede yanılma veya aldanma ihtimalini izale etmesi gerekiyordu. Yani Tanrı dış dünya üzerine bilgimizin sahihliğinin garantörü idi. Bunun için bir yandan da özne, Rönesans'tan itibaren kendisini gösteren bilimsel hareketliliğin itici gücü olan, tarihte çok gerilere uzanan, metafiziksel/teolojik köklere sahip, evrenin matematiksel bir dili ve düzeni olduğu inancını korumak zorundaydı. Tanrı nasıl ki insana kendi ruhundan üflemişse, yarattığ1 doğaya da kendi zorunlu, mükemmel ve mutlak akılsal doğasından bazı izler ve işaretler yerleştirmiş̧ olmalıydı. Unutulmamalıdır ki, Tanrının evrendeki

8 Andre Berten, Pablo da Silveira ve Herve Pourtois (Der.), Liberaller ve Cemaatçiler, çev. B. Demir, M. Develioğlu, Dost Yayınları, Ankara 2006, s. 19, 190vd. 
izleri ve dili olarak matematiksellik, düzen/nedensellik ve her şeyin insanın emrine verildiği ve insanın en şerefli/en merkezi varlık olduğu fikri, bilimin ortaya çıkmasını sağlayan metafiziksel/teolojik köklerdir.

Leibniz bir adım daha ileri giderek, evrendeki varlıkların yapı taşlarını oluşturan monadların dışarıya açık pençelerinin olmadığını, dolayısıyla her bir monadın kendi kendine yeter olduğunu ve kendiyle özdeş olduğunu ve yine her bir monadın tasarımlama gücüne sahip olup kendi içinde tüm evrenin bir tasarımını barındırdığını, bir bakıma monadın kendi kendine yeter bir mikro evren olduğunu öne sürmüş ve Descartes'in öznesini çok daha güçlü ve sarsılmaz bir temele oturtmuştur.

Spinoza ise sözünü ettiğimiz özneyi Tanrısal bir doğa ve güçle donatmış, bir anlamda onu tanrısallaştırmıştır. Onun sözleriyle, “Usun doğası şeyleri olumsal olarak değil ama zorunlu olarak görmektir. . şeyleri bu bengilik doğası altında görmek usun doğasına özgüdür."9 Şeyleri zorunlu olarak gören [şeyleri olumsallaştıran duygulardır] usun bu doğasının gerisinde Tanrı vardır. Çünkü “İnsan anlığı Tanrının sonsuz anlığının bir parçasıdır. İnsan anlığı Tanrının bengi ve sonsuz özünün yeterli bir bilgisini taşır."10 Öyleyse aklıyla tutkularına hakim olan ve hayatını aklın kılavuzluğunda sürdüren bir kişi, her şeyin içkin zorunlu nedeni olan ve tek kendi doğasına göre özgürce eyleyen Tanrıya benzemiş olur.

Descartes, Leibniz ve Spinoza'nın kendi kendine yeter, kendi kendinin nedeni, sonsuzlukla donatılmış özgür ve muktedir öznesi, Kant tarafından miras alındıktan sonra metafiziksel/teolojik dayanaklarından yoksun bırakılarak tamamen dünyevileştirilmiş ve bugün cari olan Modern özneye dönüştürülmüştür. Öznenin konumunu daha da sağlamlaştırmak için Kant, Tanrıyı teorik olarak içi boş bir kavrama - çünkü algısız kavram boştur - dönüştürmüş ve bilgi sınırlarımızın ötesine, bilinmezliğe, nomenlerin dünyasına fırlatmıştır. Her ne kadar nomenal bir varlık olması itibariyle öznenin de bilinemezliğini vurgulasa da ona, tecrübelerin sistemli birliğini sağlamak ve fenomenler üzerine bilgimize kesinlik ve zorunluluk kazandırmak adına kurucu ve kritik bir rol vermekten geri durmamıştır. Artık Kant’ta özne, sahip olduğu apriori görü ve

\footnotetext{
B. Spinoza, Törebilim, s. 67-68.

B. Spinoza, Törebilim, s. 42, 43, 69.
} 
zihin formlarılya gerçekliği inşa etmeye muktedir bir varlık olmuştur. Dolayısıyla özne artık, gerçekliğe/dünyaya ilişkin tüm unsurlardan ve yapılardan önce gelen ve gerçekliği/dünyayı kendine, kendi yasalarına göre inşa eden bir varlıktır. Aynı özne, kendi nesnel, zorunlu ve evrensel yasalarıyla ahlakın da mihenk taşı olmuş, ahlaki ilkenin arzuya, çıkara, duygulara, yani pragmatizme kurban edilerek görelileştirilmesine asla izin vermemiştir. Aslında Kant, Tanrının insanlık tarihi boyunca insanların ahlaki hayatlarında sahip olduğu ve sürdürdügü mutlak egemenliği ve otoriteyi, bir kez Tanrıyı teorik aklın kılıcıyla alaşağı ettikten sonra, özneye devretmiş ve ahlaki deneyimde özneyi neredeyse Tanrı kadar kendisinden korkulması ve kendisine huşu içinde saygı duyulması gereken çünkü onun sesi en kan dökücü varlığınkinden bile daha korkutucudur ve yasası da kutsaldır- bir varlığa dönüştürmüştür. Bundan böyle ahlak alanında bile Tanrıya ihtiyaç yoktur çünkü özerk öznenin iyinin ne olduğunu bilebilmesi ve ahlaken kendisini belirleyebilmesi için bir Tanrıya ihtiyacı kalmamıştır. Ahlaken ihtiyacı olan her şey kendisinde/aklında mevcuttur.

Kant öznenin hiçbir zaman görünmez ve her şeye kadir Tanrı gibi olamayacağını derinden hissettiği için ve ayrıca kendi koşulsuz buyruklarına harfiyen uyan öznenin ahlaklılığg ölçüsünde mutluluğu bulamayacağını - çünkü doğru söyleyen dokuz köyden kovulur - ve hatta duygularının ve arzularının sesini sürekli bastırdığ için bu işin bir süre sonra ona ağır geleceğini, zamanla ahlaki motivasyonunu kaybedeceğini çok iyi bildiği için, teorik aklın kapısından kovduğu Tanrıyı şimdi kendi ahlak görüşünü güçlendirebilmek, öznenin ahlaki yaşantısında itici bir güç olarak kullanabilmek adına pratik aklın bacasından içeri alır. Ve bize şunu söyler: Aklın koşulsuz buyruklarını aynı zamanda Tanrının buyruklarıymış gibi gör ve her daim seni gözetleyen bir Tanrı varmış gibi yaşa - bu, Kant'ın önemsediği zihniyet dinidir- ki ölümden sonra, hak edip de karşılığını bu dünyada bulamadığın mutluluğa Tanrının cennetinde - En Yüksek İyi - nail olasın. "Gelgelelim, gelecekteki ödül uğruna 1stıraba katlanmaya gönüllü olmanın bireysel ödüllerden toplumsal ödüllere, bir kimsenin cennet konusundaki umutlarından torunları konusundaki umutlarına aktarılabilir hale geldiği görüldü."11 Tanrı ahlaki tecrübe sahasında da işini kaybettikten

11 Richard Rorty, Olumsallık, Irroni ve Dayanışma, çev. M. Küçük ve A. Türker, Ayrintı Yayınları, İstanbul 1995, s. 130 

sonra, neyi nasıl bilmesi, nasıl yaşaması ve nasıl kimlik kurması gerektiği konusunda kendi kendisinin efendisi olan özerk özne, aklın ve bilimin rehberliğinde kendi özne nosyonunu sağlamlaştıracak ve evrenselleştirecek, topluma rasyonel biçim ve düzen verecek, geleceği öngörüp güvenceler yaratacak, doğayı dilediğince kullanıp dönüştürecek ve dünyanın hakimi olacaktır. İşte bu, modernizmin kökeni, temeli ve büyük utkusudur.

Aklın ve ayırt edici vasfı rasyonellik olan öznenin Tanrıyla bağlarının koparılması demek, onun yanılabilirliğini, duyguların esiri olduğunu, belli bir tarihin, geleneğin, sosyo-kültürel bağlamın kuşatması altında olup koşullandığını ve dolayısıyla hiçbir zaman kendi kendine yeter ve kendi kendinin özgür nedeni olma vasfına sahip olamayacağını ve dahası nesnel, evrensel, mutlak ve zorunlu yasaların, ezeli-ebedi doğruların sahibi ve yaratıcısı olamayacağını kabullenmek demekti. Dolayısıyla "Tanrının yerine insanı geçirmenin bir alemi yoktu. Bu, sadece Tanrının vefatıyla yüzleşmekten kaçınmak için uydurulmuş bir başka kurnazca hileydi. Dinin putperestliğinin yerine hümanizmin putperestliğini geçirmek bize hiçbir şey kazandırmazdı. İkisinin amentüsü de, birlikte ayakta durur ya da birlikte düşerdi. Tanrının ölümü, beraberinde Tanrının yeryüzündeki suretinden ibaret olan İnsan'ın da ölümünü gerektirmeliydi."12 Ne yazık ki, Aydınlanma ve Modern proje bu acı gerçeği kabullenmeye cesaret edemedi ve Tanrının kudret fışkıran mutlak tahtının cazibesine tutuldu. Aksi halde, Hume gibi, metafiziği ve teolojiyi yerle bir ettikten sonra, aklın duyguların esiri olduğunu, onsuz bilimin asla mümkün olamayacağı düzen ve nedensellik fikrinin tamamen bir alışkanlık ürünü olduğunu - yani nesneler ve olaylar arasında zorunlu bir bağlantının bulunmadığını, bulunsa bile bunun algılanamayacağını, varlıkların ve evrende gerçekleşen her şeyin zorunlu değil olumsal bir karaktere sahip olduğunu - ve elimizde sadece olasılıklı konuşmamıza imkan veren tahmini karakterdeki bir bilginin olduğunu dürüstçe itiraf etmesi gerekirdi. Ne var ki modernlik söylemleri “bir Tanrının mukadder kıldığ1 tözsel bir iyi ve doğru nosyonunun dayatılmasını reddeder; ama birçoğu bireyden önce ve bireyin ötesinde var olan, insanlar tarafından keşfedilecek, bilinecek ve izlenecek dünyevi değerlerin ve kuralların tanınması düşüncesini kabul eder. Akıl farklı yollarla

12 Terry Eagleton, Kuramdan Sonra, s. 202. 
özgülleştirilebilmesine rağmen, özgür bireylerin uğraşlarının götüreceği bir gönderme noktası olarak başvurulacak bireyüstü ve belki de insanüstü bir kategori olarak görülmüştür."13 Bu insanüstü Akla tapma ve iman etme, modern çağın en aklı başında, en ayakları yere basan düşünürlerinin bile tanımlayıcı vasfı olmuştur. Geçmişte olduğu gibi modern çağda da akla insanüstü, nötr, evrensel ve yasakoyucu bir konum atfeden akılcı düşünürler, duygulanımı aklın en zararlı ve tehditkar düşmanı olarak ilan etmişler ve duyguları ve duygusallığı neredeyse hayvanilik, ilkellik ve canilikle eşleştirmişlerdir. Rasyonelliğe çokça vurgu yapan Russell'ın sözleriyle "gerçekten de şiddetli duygusallık, görüş sahibinin rasyonel kanıtlardan yoksun olduğunun bir göstergesidir. Politika ve din konularındaki görüşler hemen hemen tümüyle aşırı duygusallık ile bağıntılı türdendir."14 Yanılabilirliğimizi vurgulayan, bilgiye yanlışlamalarla ulaşabileceğimize inanan, tartı̧̧ma ve eleştiriyi son derece önemseyen hoşgörülü Popper dahi Russell'dan farklı değildir: "Kuvvetle inanıyorum ki, akıldışıcılığın duygulanım ve tutkular üzerindeki bu ısrarı, ancak cinayet olarak betimleyebileceğim bir sonuca varır. Bunun bir nedeni, en iyisinden, insanların akıldışıcı yapılarına boyun eğmek, en kötüsünden, insan aklını hor görmekten ibaret olan bu tutumun herhangi bir anlaşmazlıkta hakem olarak şiddete ve hayvani güce başvurulmasına yol açacağıdır." 15 Kaprissiz, duygu ve arzularına göre hareket etmeyen Tanrının ruhu hala aramızda dolaşmakta galiba!

Sonuç itibariyle, Aydınlanma düşüncesi, dinin sekülerleştirilmiş bir versiyonudur ya da sekülerleşmiş dindir. ${ }^{16}$ Modernist söylem ve proje de böyle bir dinin temelleri üzerine kurulmuştur. Foucault'nun dikkat çekici analizlerinin işaret ettiği gibi, Modern devlet, kökeni Hıristiyan kurumlarında olan ve yüzyıllardır dinsel kuruma bağlı kalmış bir iktidar tekniğini, pastoral iktidarı yeni bir

13 Peter Wagner, Modernliğin Sosyolojisi, s. 33, 34.

14 Bertrand Russell, Sorgulayan Denemeler, çev. N. Arık, Tübitak Yayınları, Ankara 1998, s. 3.

15 Karl Popper, Açık Toplum ve Düşmanları, Cilt 2, çev. Harun Rızatepe, Liberte Yayınları, Ankara 2008, s. 302.

16 Peter Wagner, a.g.e., s. 40; Max Horkheimer, Akıl Tutulmasl, s. 62 vd.; Jacques Derrida, "İnanç ve Bilim", Din, J. Derrida ve G. Vattimo (der.), çev. D. Kundakçı ve M. E. Özcan, Dost Kitabevi Yayınları, Ankara 2011, s. 30 ve 35. 
biçime sokarak, yani sekülerleştirerek uygulamıştır. ${ }^{17}$ Tanrının yerine akıl, kutsal kitabın yerine bilim, peygamberlerin yerine bilim adamları ve uzmanlar, ümmetin yerine rasyonel toplum, kulun yerine özerk özne, inayetin yerine tarih ve cennetin yerine bu dünyada daha iyiye ve gelişmişliğe, selamete doğru ilerleme konmuştur. Akıl, doğa, bilim, ekonomi, demokrasi, insan hakları, özgürlük, rasyonellik, evrensel ahlak, adalet vb. kutsallar ve mutlaklar modernizmin şanlı tarihinin azizleri ve kahramanları olmuşlardır.

Ne var ki, Tanrıyı oynayan atomik özne bir süre sonra, tıpkı kanlı ellerinde can veren Tanrı gibi, kendi kendinin nedeni özgür bir fail olmakla birlikte, yalnızlığa ve tekliğe, bilinemezliğe mahkum olmuş, zorunluluk çukuruna gömülüp kalmış, zamanın, mekanın, tarihin ve geleneğin üstüne yükselerek soyut ve hareketsiz bir nesnellik ve evrensellik hayaletine - her an her yerde olan bir hayalete - dönüşmüş, korkutucu, gözetleyici, disipline edici, müdahaleci ve geleceği takdir edici bir hüviyete bürünmüştür. Tam bu noktada, modernlik projesi kendisini, onu neredeyse imkansızlaştıran, onun kendi kendisini geçersizleştirmesine yol açan bir paradoksun içinde bulur. O bir yandan özgürlük ve özerkliğin imkanı olarak baş göstermişken - özellikle Adorno, Horkheimer, Marcuse ve Foucault'nun açıç̧a gösterdikleri üzere - bireyi gözetleyen, tabi kılan, disiplin altına alan, tektipleştiren bir söyleme ve pratiğe dönüşmüştür. Yani, o bir yandan özgürleştiricidir ama aynı zamanda tabi kılıcı, birey üzerinde tahakküm kurucu ve disiplin altına alıcıdır. Bu, modernizmin indirgenemez çifte doğası, çözümsüz paradoksudur. ${ }^{18}$ Bir yandan da özerk ve atomik özneleri bir arada tutacak ve aralarında sahici ve dayanışmacı ilişki yaratabilecek bir birlik, ortaklık harcı, topluluk ruhu oluşturma kaygısının yarattığı ağrı ve gerilim, modern toplumsal ve siyasal projeler tasarlayanların başından hiç eksik olmamıştır. Özgürlük ve tahakküm/kader, birlik ve çokluk problemi ve paradoksu can alıcı niteliktedir. İtiraf edelim ki, bir zamanlar teologların, kelamcıların ve din felsefecilerinin başını ağrıtan aynı sorunlar farklı biçimlerde modernizm tartışmalarında kendisini göstermektedir. Bir yanda tarihselciler, bağlamsalcılar diğer yanda evrenselciler, bir yanda gelenekçiler, cemaatçiler, cumhuriyetçiler diğer yanda yükümsüz özne savunucusu liberalistler, anarşistler, bir yanda güveni ya da eşitliği önceleyenler diğer yanda

17 Geniş bilgi için bkz. Michel Foucault, Özne ve İktidar, çev. I. Ergüden ve O. Akınhay, Ayrıntı Yayınları, İstanbul 2005, s. 65-67.

18 Peter Wagner, Modernliğin Sosyolojisi, s. 30-33. 
özgürlükçüler, bir yanda iyinin önceliğini savunanlar diğer yanda adilin önceliğinden ödün vermeyenler, bir yanda bireyin özgürlüğü adına devleti ortadan kaldıran ya da minimize edenler diğer yanda ulus devletçiler, cumhuriyetçiler, bir yanda farklılık ve çoğulculuk sözcüleri diğer yanda birlikçi, evrensel bir rasyonaliteye veya konsensüse dayalı dışlayıcı, baskıcı veya en iyisinden uzlaşmacı söylemler.

Bütün bunlar bize açıç̧a gösteriyor ki, Tanrı gerçekte öldürülememiştir. Sözümona aydınlanan insan, Tanrının tahtını elinden almış ve o tahta kendisi oturmuş, Tanrıdan kalan ganimet ve mirasın üzerine konmuş ve bir Tanrı gibi krallık sürmekten kendini alamamıştır. İşte geldiğimiz tam bu noktada postmodernistlerin itirazları yükselmeye başlar. Postmodernizm, modernizmin aşırılıklarına bir tepki, modernizmle hesaplaşma; akıl tanrısına, bilim peygamberlerine, rasyonellik ve bilimsellik kutsal kitabına, rasyonellik ve bilimsellik sancağı altında toplanmış düzenli, güvenli, disiplinli, tektipleşmiş ümmete ve cemaate, ilerleme ve gelişme cennetine isyandır. Tepkinin, hesaplaşmanın ve isyanın tek bir sebebi vardır: Özgürlük. Postmodernistler, "Modernliğin artık özgürleştirici bir güç değil, bir boyun eğdirme, baskı ve ezme kaynağı olduğunu ileri sürerler"19 ve sahici bir özgürlük için temelsizliği, göreliliği, farklılığı, çoğulculuğu, olumsallığı dillendirirler. Bu yüzden, tek bir kod, tek bir dil, tek bir hakikat dayatan her şeye saldırırlar.

Aslında postmodernizm, insanın asla tanrı olamayacağını, tanrıyı oynayamayacağını söylemek ve göstermekten öte bir şey değildir. Postmodernistler kralın çılaklığını haykıranlardır. Nietzsche'nin eşsiz aforizmatik sözünün işaret ettiği gibi, “Göbeğimizin altı, insanın neden kendini bir Tanrı yerine koyamadığının sebebidir." ${ }^{20}$ Postmodernizm, Aydınlanma ve Modernizme meşruluk kazandıran dinden/Tanrıdan miras temelleri ve duvarları yıkarak insanın kendisini olduğu gibi, yani arzuların oyuncağı, kırılgan, acıya duyarl, özgürlüğe mahkum ve kaygill; sağlam, zorunlu ve evrensel bir temelden ve zeminden yoksun, dilin, tarihin ve kültürün zincirleriyle tutsak, kendisine ve geleceğe ilişkin herhangi bir güvenceden ve dayanaktan yoksun olumsal bir varlık olarak kabul etme cesaretini göstermesi için bir kışkırtmadır, silkelemedir ve bir

19 Pauline Marie Rosenau, Post-Modernizm ve Toplum Bilimleri, çev. Tuncay Birkan, Bilim ve Sanat Yayınları, Ankara 2004, s. 23.

20 F. Nietzsche, İyinin ve Kötünün Ötesinde, çev. Ahmet İnam, Say Yayınları, İstanbul 2009, s. 90. 
davettir. Bu yüzden postmodernizmin Tanrıyı - yani, ezeli-ebedi hakikati - ikinci kez öldürmesi ama bu sefer gerçekten öldürmesi gerekiyordu. Nietzsche'nin Tanrıyı öldürmesi, öyle görünüyor ki, postmodern düşünce için bir milat olmuştur. Bundan böyle Tanrısız, "görece ve geçici biçimde, temeller olmadan yaşama cesaretini göstermek zorundayız." ${ }^{21}$ Artık bilginin değil, evrensel uzlaşımın değil, sonsuz ve mukayese edilemez anlam ve yorumların dünyasındayız. Çünkü "postmodern teori, teorinin gerçekliği yansıttı̆̆ 1 yollu modern inancın ve temsilin eleştirisini yaparak, teorilerin kendi nesneleri üzerine en iyi ihtimalle kısmi perspektifler sunduğunu ve dünyaya ilişkin tüm bilişsel temsillerin tarihin ve dilin dolayımından geçtiğini savunan 'perspektifçi' ve 'görecelikçi' konumlara yerleşir." 22

Postmodernizmin, modernizmin tamamlanmamış bir projesi ve parçası olup olmadığı, tarihin veya toplumsal oluşumun modernizmden farklı ve yeni bir aşamasına işaret edip etmediği, bir şeylerin sonu olup olmadığı, iyimserliğe ve hoşgörüye mi yoksa karamsarlık, kaotiklik, saçmalık ve melankoliye mi hizmet ettiği, sistemli, tüm postmodernist söylemleri kuşatıcı ve sağlam bir teorisinin olup olmadığı tartışmaları çok önemli değildir. Önemli olan, çok ses getirdiği ve hala da ses getirmeye devam ettiğidir. Çünkü postmodernistlerin, modernizmin hastalıklarına, aşırılıklarına, zayıflıklarına ilişkin tanıları ve analizleri son derece dikkat çekici ve sarsıcıdır. Her şeyden önemlisi, postmodernizme yönelik ilginin gerisinde duran esas sebep ve tabi ki ona ilişkin takdir edilesi yön, onun özgürlük adına Aydınlanma ve Modernizmle hesaplaşması ve bunlara karşı kavga vermesidir. Mesele, özgürlük ve özgürleşme meselesidir. Birçok postmodernist diye nitelenen düşünürün, sözgelimi Lyotard'ın, Foucault'nun, Bauman'ın, Rorty'nin, Deleuze'un eserlerinde bunu rahatlıkla görebilirsiniz. Hepsi de farklılığa, çoğulculuğa, olumsallığa, bireyin tahakkümden kurtuluşuna gidecek yolları açmaya ve böylelikle sahici - modern versiyonundan farklı olarak belirsizliğe, temelsizliğe, karar verilemezliğe, farklılı̆̆a, çoğulculuğa, olumsallığa ve sorumluluk bilincine dayanan - bir özgürlügün imkanını yaratmaya çalışmıştır. Bauman'ın sözleriyle, postmodernlik "Büyük toplumsal tasarımlara duyulan yaygın nef-

21 Terry Eagleton, Kuramdan Sonra, s. 202

22 Steven Best, Douglas Kellner, Postmodern Teori, çev. Mehmet Küçük, Ayrıntı Yayınları, İstanbul 1998, s. 18. 
retin, mutlak hakikatlere duyulan ilgi kaybının, kurtulma güdülerinin özelleştirilmesinin, bütün yaşam tekniklerinin göreceli - salt keşfe yönelik - değeriyle uzlaşmanın, dünyanın iflah olmaz çoğulluğunun kabul edilmesidir. Özünde çokanlamlı ve tartışmalı olan postmodernlik düşüncesinin (yalnızca zımnen de olsa) çoğunlukla işaret ettiği şey, her şeyden önce, dünyanın ortadan kaldırılması imkansız çoğulluğunun kabulüdür. Aynı şekilde, postmodernlik, müphemliğin üstesinden gelmeyi ve aynılığın tekanlamlı kesinliğini hedefleyen tipik modern güdüden tamamen özgürleşme anlamına gelir. Gerçekten de postmodernlik, tektiplilik ve evrenselcilik gibi modernliğin merkezi değerlerinin işaretlerini tersine çevirir. Postmodernlik, kendi imkansızlığıyla uzlaşan - iyi ya da kötü, bununla birlikte yaşamaya kararlı olan - modernliktir."23

Postmodernistlerin özgürleşme adına neleri başardığını ise özlü bir biçimde Terry Eagleton'un postmodernlik tanımında buluruz: "Postmodernlik klasik hakikat, akıl, kimlik ve nesnellik nosyonlarından, evrensel ilerleme ya da kurtuluş fikrinden, bilimsel açıklamanın başvurabileceği tekil çerçeveler, büyük anlatılar ya da nihai zeminlerden kuşku duyan bir düşünce tarzıdır. Postmodernlik, Aydınlanma'nın bu normlarına karşı dünyanın olumsal, temelsiz, çeşitli, istikrarsız, belirlenmemiş nitelikte ve bir dizi dağınık kültürlerden ya da yorumlardan ibaret olduğunu bildirir; bu da hakikat, tarih ve normların nesnelliği, doğanın verili oluşu ve kimliklerin tutarlılığ Böylece postmodernliğin farklılıklara açık ve çoğulcu dünyasında bütün yaşam biçimleri baskılanmadan, ötekileştirilmeden, yabancı muamelesi görmeden barış içinde yaşayabilir. “Özgürlük, eşitlik ve kardeşlik, modernliğin sloganıdı. Özgürlük, farklılık ve hoşgörü ise postmodernliğin ateşkes formülüdür." ${ }^{25}$ Postmodernlikle birlikle eskinin erdemleri günaha dönüştü, eskinin günahları ise yeniden itibarlarına kavuşuyor. Modernliğin yıkmaya çalıştığı şeyler bugün intikam alıyor. Ve artık kesin olan bir şey varsa, o da, Bauman'ın sözleriyle, "kabileler ve kabilecilik çağında yaşadığımızdır.

23 Zygmunt Bauman, Modernlik ve Müphemlik, çev. İsmail Türkmen, Ayrıntı Yayınları, İstanbul 2003, s. 130-131.

24 Terry Eagleton, Postmodernizmin Yamılsamaları, çev. Mehmet Küçük, Ayrıntı Yayınları, İstanbul 1999, s. 9; Benzer tanımlama için bkz. Pauline Marie Rosenau, Post-Modernizm ve Toplum Bilimleri, s.26.

25 Zygmunt Bauman, Modernlik ve Müphemlik, s. 131. 
Bugün cemaat övgüsüne, aidiyetin alkışlanmasına ve heyecanla gelenek aramaya enerji, güç ve canlılık veren şey, mucizevi bir biçimde yeniden doğan kabileciliktir. En azından bu anlamda modernliğin uzun ve dolambaçlı yolu bizi bir zamanlar atalarımızın yola çıktığı başlangıç noktasına getirdi." 26 Toynbee, Mills, Bell, Steiner, Baudrillard gibi bozulma, kokuşma, çöküş, infilak benzeri olumsuz söylemler üretenleri görmezden gelecek olursak, postmodernizm eskinin büyülü bahçesinin - tabi ki mutlaklar, ezeli-ebedi hakikatler, nihai temeller olmaksızın - küllerinden doğması ve yeniden canlanmasıdir.

\section{Tanrının Ölümü Öznenin de Ölümü Demektir}

Nietzsche'nin gündüz elinde fenerle Tanrının öldüğünü haykıran delisi, postmodern düşünce için bir dönüm noktası olmuştur. Çünkü o deli, Tanrının ölümünü haykırırken varlığın, öznenin, dilin, hakikatin, tarihin, toplumun vs. mutlak bir temelden ve sabit bir anlamdan yoksun olduğunu dile getiriyordu. Bu yüzden, Nietzsche'den derin etki ve izler taşımayan postmodernist düşünür neredeyse yok gibidir. $\mathrm{O}$, postmodern düşüncenin gerçek mimarıdir.

Nietzsche'nin de önemli bir temsilcisi olduğu varoluşçuluk verilmiş, - arzuların ve tarihselliğin lekelerinden ari - evrensel ve tözsel bir mahiyete ve nesnel, buyurgan bir dile sahip egemen özne anlayışının karşısına akıl ve bilimle asla içine nüfuz edilemeyen, daha ziyade öznel hakikatte, tam anlamiyla nesnel belirsizlikte açığa çıkan, paradoksal, kırılgan, emniyetten yoksun, fırlatılmış, irrasyonel bireyi koymuştur. Rousseau'da, Adorno'da ve Horkheimer'da olduğu gibi varoluşçularda da hakim tema özgürlüktür, özgürlük arayışıdır. Rasyonellik ve bilimsellik insanı köleleştiren, kendine yabanclaştıran bir mahiyet arz etmektedir ve bireyin özgürlüğü ve içsel değerler adına buyurgan akla, toplumun rasyonel düzenlenişine, modern özne fikrine bir saldırı vardır bu düşünürlerde. Varoluşçu düşünceye göre, tıpkı modern özne fikrinde olduğu gibi, insan kendi seçimlerinden ve projelerinden ibarettir, yani onun önceden belirlenmiş bir özü, tarih ötesi bir evrensel zemini yoktur. Yani insan, ancak kayısı ağacı olmak zorunda olan bir kayısı çekirdeği değildir. İnsan kendi karar ve seçimleriyle kendi kendisini kurar. Ancak, modern özne için söz konusu olduğu gibi, nesnelliğin,

26 Zygmunt Bauman, Postmodernlik ve Hoşnutsuzluklarl, çev. İsmail Türkmen, Ayrıntı Yayınları, İstanbul 2000, s. 111-112. 
rasyonelliğin, zorunluluğun, doğallığın, bilimselliğin nihai ölçüt ve evrensel yasa kabul edildiği yerde karar verme yetkisi ve sorumluluk bireyin elinden alınmış ve birey özgürlüğünden mahrum edilmiş olur. Oysa "insan bir kezliktir ve bir kezlik şeyi yapar." ${ }^{27}$ Birey ancak tam bir bilgisizlik durumunda, neyin seçilmesi ve neye karar verilmesi gerektiği konusunda rasyonel ve bilimsel bir güvencenin olmadığ rar. Karar tamamen kendisine ait olduğu için de eylemin tam anlamıla failidir ve eylemin bütün sorumluluğu ona aittir. Muktedir egemen öznenin tersine, kırılganlık, hiçlik, ölüm, belirsizlik, zamansallık, karar ve sorumluluk, sahici varoluşun imkanıdır varoluşçular için. Varoluşçuların özgürlüğü temelsizlikte, irrasyonellikte, öznel hakikatte, belirsizlikte, güvencesizlikte, tarihsel ve dilsel olumsallıklarda açı̆̆a çıkarmaları ve mümkün hale getirmeleri, insanın asla Tanrıyı oynayamayacağının, insanın ölümlüğünün, sınırlılığının, temelsizliğinin bir ilanıdır aynı zamanda. Aynı zamanda bu, farkl1lığın ve çeşitliliğin de bir onaylanışıdır. Bu açıdan varoluşçuluk, postmodern düşünceyi besleyen en bereketli kaynak olmuştur. Yine, bütün anlamın, gerçekliğin, kendilik imkanının, özgürlüğün ötekiyle karşılaşmada - Kierkegaard'ın Tanrıyla karşılaşan İbrahim'i ya da Buber' in Ben ve Sen'i - ortaya çıtı̆̆ğ ve ötekinin, sonsuz sorumluluğun kaynağı olduğu görüşü, Gadamer'in diyalojik konuşması ve oyunu ile postmodernizmin öznelerarasıllğı ve etik düşüncesi için ilham kaynağı olmuştur.

Varoluşçular içerisinde özellikle Nietzsche postmodern düşünce için çok önemli bir yere sahiptir. Çünkü o, Tanrıyı öldürmekle özneyi de öldürmüş, Tanrıyı oynama düşüncesini ve imkanını insanın elinden ebediyen almıştır. Hem Tanrı hem de özne kurgusunun temelinde yatan "görünen" ve "gerçek" ayrımının bir hastalık belirtisi olduğu kanaatindedir Nietzsche. ${ }^{28}$ Dolayısıyla Tanrı ve özne zemini üzerine dayandırılan felsefe, din ve ahlak sadece yozlaşmanın ve oluşun masumiyetinin kirletildiğinin belirtileridir. Tanrı ve özne gibi tözsel tasavvurlar ve bunlara bağlı geliştirilen mutlaklık, nesnellik, gerçeklik ve evrensellik, gerçekliği olan şeyler değildir. Bunlar olsa olsa, arzunun ve dilin yaratımlarıdır. Bunların gerisinde, değişkenlik, akışkanlık, kırılganlık, temelsizlik ve faniliği hazmede-

27 F. Nietzsche, Güç İstenci, çev. Sedat Umran, Birey Yayıncılık, İstanbul 2002, s. 449 .

28 F. Nietzsche, Güç İstenci, s. 301. 

meyenlerin 'ölümsüz, istikrarlı, mutlak bir varlık ya da dünya olmalıdır' arzusu vardır. Nietzsche'nin sözleriyle, "Nesnelerin teşekkülü kesinkes tasavvur edenin, düşünenin, isteyenin, hissedenin eseridir. Hatta özne, böyle bir yaratılmış olandır, bütün diğerleri gibi bir nesnedir." ${ }^{29}$ Nietzsche, özneyi, bizdeki birçok ruh durumlarının ve bilinç anlarının bir tözün, bir birliğin sonucuymuş gibi görüldüğü bir kurgu olarak değerlendirir ve aslında öznenin faniliğine, kaçıcıllğına ve bir bedendeki özneler çokluğuna göndermede bulunur. Yine onun sözleriyle, "Bir öznenin kabulü belki de zorunlu değildir; belki de öznelerden çokluğu adamakıllı düşünebiliriz ki onların birlikte oyunu ve mücadelesi düşünüşümüzün ve denilebilir ki bilincimizin esasını oluşturur. İçlerinde egemenliğin var olduğu hücrelerin bir tür aristokrasisi değil midir?"30

Tanrının ölümüyle birlikte töz ve öznenin de ölümünü muştulayan Nietzsche devamında Tanrının varlığı inancının bir kalıntısı olan hem idealistik hem de pozitivistik "gerçek dünya" ya da "gerçeklik" düşüncesini yerle bir etmeye yönelir. "Bir gerçek dünya - Bu bize yapılan en garip şaka ve saldırıdır. Dünyanın değerinin bizim yorumumuzdan kaynaklandığı doğrudur. Tek başına bilgi ne olabilir? 'Yorum', bir şeyin içine anlamı koymak, 'açılamak' değil. Hiçbir olgu bağlamı yoktur, her şey akıcıdır, kavranamazdır, elimizden kaçandır, en devamlısı bizim görüşlerimizdir. 'Gerçek ve görünür dünya' kavramının eleştirisi. Bunlardan ilki sırf bir fiksiyondur, sadece, sirf zihnen uydurulmuş şeylerden oluşur. Görünen dünya, bu demektir ki değerlere göre görülen bir dünya. . . Değerlerimiz nesnelerin içine yorumlanmıştır. Nesnelerin teşekkülü, kesinkes tasavvur edenin, düşünenin, isteyenin, hissedenin eseridir. Gerçek, orada var olan ve bulunacak, keşfedilecek olan bir şey değildir, tersine yaratılması gereken bir şeydir. Hayır, düpedüz olgular yoktur, sadece yorumlar vardır. Biz 'zati' olarak hiçbir olguyu tespit edemeyiz. Belki de öyle bir şeyi istemek saçmalıktır. İnsan sonunda nesnelerde onun içine sokup yerleştirdiğinden daha başka bir şeyi bulamaz. Tekrar bulmanın adı bilimdir. [Dünya] başka türlü yorumlanabilir, ardında bir anlamı yoktur, tersine sayısız anlamları vardır: Perspektivizm." 31

\footnotetext{
F. Nietzsche, Güç İstenci, s. 282.

F. Nietzsche, Güç İstenci, s. 254.

F. Nietzsche, Güç İstenci, s. 251, 280, 285, 286, 299, 302,305, 307.
} 
Gerçek dünya diye bir şey yoksa hem bilimin hem de dinin gerçekliğe referansla bahsettiği hakikatler seyyar metafor ordusu, kaypak bir yığın, hayal olduğunu unuttuğumuz hayal, üzerindeki kabartmaları silinmiş olup artık bozuk para niteliği bile taşımayan metallerdir. Bilimin ve dinin hakikatleri, gerçeğin bilgisini aktarmak şöyle dursun, tiranlığın araçlarıdır, güçsüzlüğün işaretleri olup bu yüzden egemen olma isteğinin dışavurumudur. ${ }^{32}$ "Bu bilim ve çileci ideal ikilisi, aynı temele dayanırlar - bunu zaten göstermiş bulunuyorum -; İkisi de, hakikati çok büyük görme üstüne dayanırlar (daha doğrusu: Hakikatin değerlendirilemez ve eleştirilemez olduğu inancı üstüne). Bundan dolayı onlar zorunlu müttefiktirler, eğer savaşacaklarsa, birlikte savaşırlar, birlikte sorgulanırlar. Çileci idealin değerinin küçük görülmesi kaçınılmaz olarak bilimin de küçük görülmesini içerir." 33

Açıkça görüldüğü üzere Nietzsche, hayatın özü olarak değer koymanın önemine işaret etmekte ve olgularla değil de tamamen değerlerle yaratılan ve sonsuzca yorumlanan dünyalardan bahsetmektedir. Bu Nietzsche için, hem hayatın kısıtlanması, seviyesinin alçaltılması demek olan bilimin ve dinin tiranlığından kurtuluşun anahtarıdır ve hem de bir sanatçı üslubu ile sonsuzca anlamlandırmalarla ve yorumlarla, renklerle ve notalarla yaratılmayı bekleyen dünyaların müjdesidir, yani özgürlüğün ve bir sanatçı edasıyla yaratıcllğın yüceltilmesidir. Nietzsche'nin gözünde, özgürlük ve yaratıcılık, hakikati değil, hakikat olmayanı, yani belirsizliği, bilgisizliği gerektirir. ${ }^{34}$ Dolayısıyla özgür ve yaratıcı insan, belirsizlikten zevk alan insandır. Özgür insan, aklının duygularının kölesi olduğunun, arzularının izinden gittiğinin farkındadır. Onun derdi, kendi hakikatini dürüstçe dile getirmek ve kendi varlığını bir sanat eseri gibi işlemek ve oluşturmaktır. Oysa bilimin ve dinin dünyasında insanlar "artık özgür ruhlar değiller: Çünkü hala hakikate inanıyorlar." ${ }^{35} \mathrm{Bu}$ inançlarıyla da dünyayı daha kasvetli, daha çirkin bir yere dönüştürüyorlar. Mutlak hakikatlere bağlllıklarıyla biricik olanı, kendine özgü olanı tektipleştiriyor ve öldürüyorlar. Belki bu

32 F. Nietzsche, Şen Bilim, çev. Levent Özşar, Asa Yayınları, Bursa 2003, s. 307; Deccal: Hiristiyanlığa Lanet, çev. Oruç Aruoba, Hil Yayınları, İstanbul 1995, s. 86.

33 F. Nietzsche, Ahlakın Soykütüğü, çev. Ahmet İnam, Yorum Yayınevi, İstanbul 2001, s. 149.

34 F. Nietzsche, İyinin ve Kötünün Ötesinde, s. 17.

35 F. Nietzsche, Ahlakın Soykütü̈̆̆̈̈, s. 146. 
Postmodernizm ve Tanrı'nın Ölümü: Öznenin Arkeolojisi Üzerine Bir Deneme

yüzden olsa gerek, Nietzsche tıpkı Kierkegaard gibi ${ }^{36}$, kalabalıklardan, toplumdan, birliklerden nefret eder. "Halk, doğanın gereksiz dolambaçlı yolu, altı ya da yedi büyük insanı yaratmak için." ${ }^{37}$

Nietzsche'nin ve onun izinden giden postmodernistlerin hakikati sorgularken tam olarak gerçekleştirmeye çalıştıkları şey, insanın hem aklın hem de dinin mutlaklarından, kesinliklerinden, gerçekliklerinden, genel geçer doğrularından, evrensel ilke ve mesajlarından, tek bir hakikat, tek bir kod, tek bir bağlam üzerine oturtulmuş, dişlayıcllık ve bölücülük karakterine sahip toplumsal yapılanmalarından, her ikisinin de yarattı̆̆ özne/kimlik modelinden ve bireysel kimlik ve özgürlügü baltalayan, insanı silikleştiren kolektif yapılarından kurtarmak ve özgürleştirmektir. Nietzsche ve müritleri, nesnel hakikat, mutlak doğru, evrensel, gerçek, töz, rasyonel, bilimsel, nesne, özne, demokrasi, doğa, yasa gibi kavramların daha çok farklılıkları ve karşıtlıkları bastırmak için kullanılan sopalar olduğunun farkındadır. Yücelttikleri, bütün teptipleştirici ve köleleştirici değerleri yıkarak yerine güç istencini, yaşama sevincini açığa çıaran, böylelikle kendine özgü değerlerini yaratan üst insandır, biricik olandır.

Nietzsche bütün kirli çamaşırlarını ifşa ederek ve bütün silahlarını elinden alarak Aydınlanmanın öznesini öldürürken, Dilthey, Heidegger ve Gadamer dünyanın dışından dünyaya bakan hayaletimsi özneyi dünyanın içine çekmiş ve onu tekrar ana yurdu olan tarihin, geleneğin ve dilin içine hapsetmiştir. Tarih, gelenek, dil vasıtasıyla kendisini anlayan ve kendisini yaratan bir özne anlayışından postmodernistlerin tümüyle tarih, gelenek ve dil tarafından yaratılan akışkan ve merkezden edilmiş öznesine geçebilmek için Wittgenstein'ın "dil oyunları"na ihtiyaç vardır. Wittgenstein felsefi kariyerinin ikinci döneminde, daha önceleri Tractatus'unda ortaya koyduğu, gerçekliği resmeden dil anlayışından ve dünyanın sınırı ve bütününü olguların resminden ibaret anlamlı cümlelerin bütünüyle eşitleyen metafiziksel iddiasından vazgeçmiş ve dilin anlamını doğrulanmasında değil - hatta ona göre bu açıdan mesele, inançların temelsizliğini kavrayabilmekte düğümlenmektedir - belli bir bağlam içindeki kullanımında aramaya başlamıştır. (O, açıça, dilimiz ile dünya arasında yapıca bir uyumsuzluk olduğunu itiraf

36 S. Kierkegaard, Günlüklerden ve Makalelerden Seçmeler, çev. İ. Kapaklıkaya, Anka Yayınları, İstanbul 2005, s. 377.

37 F. Nietzsche, İyinin ve Kötünün Ötesinde, s. 88. 
etmiş ve dolayısıyla düşünce ile gerçeklik arasında bir tekabüliyetin olduğu fikrini metafiziksel olarak nitelemiştir.) ${ }^{38}$ Ona göre, dil, caddeleri, sokakları, binaları olan bir şehre benzer. Ve bir dilin konuşulması, bir hayat tarzının parçasıdır. Dolayısıyla, bir dil tahayyül etmek bir hayat tarzı tahayyül etmektir. Bir kavramın anlamı, belli bir dilin içerisinde geliştiği hayat tarzına içkindir. Hayat tarzları çok farklı ve çeşitli olduğu için, dil çok farklı biçimlerde kullanılabilir, çok çeşitli şehirler inşa edilebilir.

Dilin, anlamını belli bir hayat tarzına veya sosyo-kültürel bağlama borçlu olduğu ve çok farklı "dil oyunları"ndan söz edilebileceği iddiasından tam bir kavramsal görececiliğe ve dilsel idealizmeWitgenstein'ın kendisi buna meyletmiş midir bilinmez ama Estetik, Ruhbilim, Dinsel İnanç Üzerine Dersler ve Söyleşiler adlı eserinde buna dönük işaretler vardır- geçiş yapmak çok kolaydır. Buna göre, her bir dil oyununun ya da hayat tarzının kendine özgü olan ve diğerleriyle mukayese edilmesi mümkün olmayan gerçeklik, anlaşılırlık, rasyonellik vb. ölçütleri ve normları vardır. Her dil kendi ölçütünü ve normlarını kendisi belirler ve koyar. Hal böyle olunca, hiç kimse içerisinde yer aldığı belli bir dilsel bağlamdan hareketle diğer diller hakkında gerçek dışılık, irrasyonellik, kötülük vs. yargısında bulunamaz. Çünkü tüm farklı dillerin üzerinde ya da temelinde yer alan evrensel ve tarafsız bir dil yoktur. Bu durumda, şayet kelimeler anlamlarını, bu kelimelerin içerisinde yer aldıkları ve kullanıldıkları belli bir bağlamdan ya da sosyo-kültürel koşullardan alıyorsa, farklı diller, farklı kavramlar demek farklı dünyalar demek olacaktır. Çünkü dünyanın nasıl bir şey olduğu, içerisinde dünya kavramının anlamlı bir kullanıma sahip olduğu belli bir kavramsal sisteme ve bu sistemin diline göreli olacaktır. Kısacası, "gerçeklik" dilden ayr1labilir bir şey olmadığı gibi neyin gerçek olduğunu belirleyen de dilin kendisidir. Öyleyse, farklı diller farklı dünyalar/gerçeklikler yaratırlar ve her dil kendi yarattığı bir dünyanın içerisinde yaşar. Sözgelimi bilim ve din, her biri dünyayı farklı betimledikleri ve birbirinden farklı dünya hikayeleri kurguladıkları için, her birinin kendine özgü dil oyunu olduğu için, birinden hareketle diğerini yargilayabileceğimiz tarafsız ve evrensel bir nokta bulunmamaktadır. Belli bir dili anlamak ve yargılayabilmek için gerekli olan şey, o

38 Ludwig Wittgenstein, “Notlar”, Felsefe ve Dil: Wittgenstein Üstüne Bir Araştırma, Ömer Naci Soykan, Kabalcı Yayınları, İstanbul 1995, s. 437 ve aynı eser içinde s. 114-115. 
dile anlamını veren hayat tarzının içine girmek, o dili içselleştirmek ve yaşamaktır. ${ }^{39}$

Eğer gerçeklik ve hakikat dile göreliyse, yani gerçekliği ve hakikati yaratan şey dil ise ve dolayısıyla bunlar tamamen insanın ürünüyse; eğer elimizde, gerçekliği/hakikati resmeden ya da temsil eden, insanın doğasına ve dünyaya ayna tutan bir dil değil de sadece tarihsel olumsallıkların kurduğu bir dil varsa; ve eğer her bir farklı dil oyununun kendine özgü bir söz dağarı ve rasyonalitesi bulunuyorsa, bu durumda dünyayı veya insan doğasını daha iyi, daha doğru ve daha gerçekçi anlatan bir dilden bahsetmek ve rasyonellik, nesnellik ve evrensellik gibi ayrıcalık, üstünlük ve saygı belirten belli bir söylemsel ölçüte göre farklı dil oyunları arasında mukayese yapmak bütünüyle imkansızlaşır. Dahası, dilin yarattı̆̆ı şey sadece gerçeklik ya da hakikat değil, aynı zamanda öznenin kendisidir de. Yani, kimliğimizi içerisinde yer aldığımız toplumsal bağlama borçluyuz. Bu, kendi kendine yeter, kendisinin özgür nedeni, yaratıcı ve kurucu işleve sahip, eylemleri üzerinde mutlak güç ve kontrole sahip öznenin ölüm fermanından başka bir şey değildir. Dünyalar yaratan özne tarihe karışmıştır. Artık kırılgan, tarihsel ve dilsel olumsallıklar ırmağında sürüklenen, yaratılan bir özne var karşımızda/içimizde. İşte böylesi bir dil oyunu anlayışından hareketle, modern özneyi ve onun evrensel etik, bilim, doğal hukuk gibi silahlarını ortadan kaldırmak, onun Tanrıyı oynayarak gerçekleştirdiği tiranlığa son vermek - ama tüm bunları özgürlük adına yapmak neredeyse bütün postmodernistlerin ortak arzusu ve amacı gibidir.

Toplumsal fenomenleri dilsel ve toplumsal yapılar, bilinçdışı kodlar, kurallar ve sistemler çerçevesinde betimlemeye girişen yapısalcı ve postyapısalcı teoride de "özne, yalnızca dilin, kültürün ya da bilinçdışının bir etkisi olarak betimlenip bir köşeye atıldı ya da radikal ölçüde merkezsizleştirildi ve öznenin nedensel ya da yaratıcı bir etkinliği olabileceği reddedildi. Yapısalcılık, simge sistemlerinin, bilinçdışının ve toplumsal ilişkilerin öncelik taşıdığını, bunların karşısında öznelliğin ve anlamın türevsel olduğunu vurguladı. Bizzat özne, dil içerisindeki bağıntıları yoluyla oluşturulmuştu. Böylece öznellik, bir toplumsal ya da dilsel inşa olarak görüldü." 40 Ancak özellikle yapısalcılığa yönelik eleştirileriyle Foucault, Derrida, Deleuze, Lacan, Barthes, Lyotard, Baudrillard ve

39 Roger Trigg, Reason and Commitment, Cambridge University Press, 1973, s. 15, 22 $\mathrm{vd}$.

40 Steven Best ve Douglas Kellner, Postmodern Teori, s. 35. 
Kristeva gibi postyapısalcı düşünürler, postmodern düşüncenin biçimlenmesinde çok önemli bir yere sahip olmuşlardır. Çünkü postyapısalcılık, yapısalcı teoride hala varlığını sürdüren değişmeyen ve evrensel bir insan doğası ya da zihin anlayışını tamamen reddetmiş ve bir temel, hakikat, nesnellik ve kesinlik arayan yapısalcıların bilimsel tutumlarına amansızca saldırmıştır. Dahası postyapısalcılar, yapısalcılardan farklı olarak, göstergenin - dil, kültür, öznellik, toplumsal ilişkiler vb. - nedensiz ve göndergesel olmayan karakterine vurgu yapmışlar, gösterilen karşısında gösterene öncelik tanımışlar ve anlamın gösterenlerin sonsuz, metinlerarası oyunu içerisinde üretildiğine dikkat çekmişlerdir. Artık olguların kaynakları ya da kökenleri biçiminde nedenler ve temeller bulma anlayışı bırakılmış, bunun yerini faillerin olmadığı yazarsız, metinlerarası bir dünya almıştır. Bir metnin anlamı - savaş, kişisel ilişki, bir seçim, akademik etkinlik, pazarlık etmek vs. hep bir metindir - daima bir başka metne götürür bizi. Ve bu metin, sonsuz yoruma açlk ve istikrarsız bir metindir ve her karşılaşmada yeniden yazılır. Metin, metnin d1şındaki bir gerçekliğe referanstan yoksun olduğu için temelsizdir, nesnel bir içerikten yoksundur ve bu yüzden okur, metni hiçbir k1sıtlama olmaksızın yorumlama konusunda sınırsız bir özgürlüğe sahiptir. Çünkü olgular değil, sadece yorumlar vardır ve dünya, hiçbir yorumun diğerlerine göre ayrıcalıklı olmadığ bir biçimde sonsuzca yorumlanmaya açıktır. ${ }^{41}$

Bununla birlikte, postyapısalcı düşünürlerin en dikkat çekici tarafı, bireylerin nasıl özneler olarak yaratıldığına, kimliklerin ve öznellik biçimlerinin nasıl oluşturulduğuna ilişkin analizleri olmuştur. Sözgelimi Lacan, öncelikle, öznenin var olduğu yerin bilinç değil, bilinçdışı olduğuna dikkat çeker. Ona göre, bilinçdışı, tıpkı dil gibi yapılanmıştır. Nasıl ki dildeki gösterenler anlamlarını gösterilenlerden, dışsal bir referanstan değil de bir başka gösterene işaret etme ve kaymalardan ve böylelikle oluşan eğretilemelerden alıyorsa - çünkü dil, anlamları kendi ayrımlarıyla belirleyen bir göstergeler sistemidir - bilinçdışı da dış dünya ile özsel ilişkisi olmayan ve kendi anlam ayrımlarını kendi iç ögeleriyle belirleyen bir tür göstergeler sistemidir. Dildeki eğretilemelere benzer şekilde, rüya gibi bilinçdışı oluşumlar da söylüyormuş gibi göründükleri şeylerden bambaşka şeyleri dile getiriler. Lacan'ın bundan sonraki adımı ise

41 Pauline Marie Rosenau, Post-Modernizm ve Toplum Bilimleri, s. 59-71; Steven Best ve Douglas Kellner, Postmodern Teori, s. 34-41. 
dilden bağımsız hiçbir öznenin mümkün olamayacağına işaret etmektir. Çünkü dil, toplumsallı̆̆ı, kültürü ve bunlarda içerilen yasa ve yasakları taşır. Dil vasıtasıyla insan, kültürel/simgesel düzene dahil olur ve henüz hiç şeyin farkına varamıyor ve hiçbir karar veremiyorken (imgesel düzen/Ayna aşaması), simgesel düzen/kültür/söylem onu yavaş yavaş biçimlendirmeye başlar ve bu yolla insan kendi kimliğini, bir gösteren olarak kendi ayrımını simgesel düzenin ilişkiler ağı ve karşıtlıkları içerisinde kazanmış olur. Dolayısıyla öznenin kimliğini yaratan şey, özneyi aşan ve onun bütün tarihini yöneten bir başkasının söylemidir. ${ }^{42}$

Foucault özellikle öznenin iktidar yoluyla üretilmesi üzerinde odaklanmıştır. Amacı, insanın özneye dönüştürülme kiplerinin, nesneleştirilmelerinin bir tarihini oluşturmaktır. Foucault'nun bütün düşünceleri neredeyse, evrensel, özsel, mutlak, zorunlu, önsel olduğu iddia edilen şeylerin tamamının aslında tarihsel olarak kuruldukları ve bunların tarihsel değişimlerin ve belli tarihsel dönemlere özgü söylemlerin ürünü olduğunu gösterme üzerine odaklanmıştır. O, öznenin tarihini yazmak istemiş ve en önemli tespitini açıkça dile getirmiştir: A priori, aşkın, kurucu, yaratıcı, özerk, evrensel, eylemlerin merkezi bir özne yoktur. Özne kendisini ancak içerisinde yer aldığı kültürü, toplumu, toplumsal grubu ve iktidar ilişkileri tarafından önerilen, telkin edilen ve dayatılan kalıplarla biçimlendirebilir. O artık merkezsiz, dağınık, çok katlı ve akışkandır. ${ }^{43}$ Bir başka ifadeyle, Foucault, "öznenin kurucu bir bilinç olmaktan ziyade kurulduğunu göstererek özneyi merkezsizleştirmeye" çalışır. ${ }^{44} \mathrm{Bu}$, bir anlamda, akıl ile özgürlüğün modern eşitleniminin reddidir ve modern rasyonelliğin ve öznellik biçimlerinin birey üzerindeki tahakkümün kaynağı olarak ifşa edilmesidir. Çünkü Foucault'ya göre, bilginin iktidar rejimleriyle kopmaz bir bağ 1 vardır ki bu, bilginin, tarafsız, nesnel veya özgürleşimci bir karakteri haiz olduğuna ilişkin modern iddiaya karşı ciddi bir meydan okumadır.

42 Postyapısalcılık ve Lacan'a dair geniş bilgi için Bkz. Madan Sarup, Post-Yapısalcllk ve Postmodernizm, çev. Abdülbaki Güçlü, Bilim ve Sanat Yayınları, Ankara 2004, s. 18-49; Meyda Yeğenoğlu ve Mahmut Mutman, "Bilimlerde ve Toplumda Postmodernizm", Birikim, Sayı: 33, 1992.

43 Michel Foucault, Özne ve İktidar, s. 100, 235.

44 Steven Best ve Douglas Kellner, Postmodern Teori, s. 58. 
"Bilgi olmadan iktidarın uygulanması, bilginin de iktidara yol açmadan var olması olanaksızdır." 45 Nihayetinde tüm söylemler iktidar tarafından üretilir ve böylelikle iktidar, gerçekliği üretir, nesne alanlarını ve doğruluk ritüellerini belirler. Buradan hareketle iktidar, bireyin kimliği, arzuları ve bedenine şekil veren politik teknolojiler, kendilik pratikleri ve normalleştirici disiplin yoluyla birey üzerinde tahakkümünü kurar. ${ }^{46} \mathrm{Bu}$ durumda insan tamamen çaresiz ve bütünüyle özgürlükten mahrum mudur? Foucault bizi tam bir karamsarlık çukuruna mı çekmektedir? Kesinlikle hayır. O, bizleri, "bireyi kategorize ederek, bireyselliğiyle belirleyerek, kimliğine bağlayarak, ona hem kendisinin hem de başkalarının onda tanımak zorunda olduğu bir hakikat yasası dayatarak doğrudan gündelik yaşama müdahale eden" ${ }^{\prime 4}$, yani yüzyıllardır bir kabus gibi insanl1ğın tepesine binip bireyleri özne yapan iktidar biçimine ve tüm öznellik ve tahakküm biçimlerine meydan okuyarak özgürleşmeye, yani kendimize özgü öznellik biçimini yaratmaya, varoluşumuza bir zarafet, üslup ve güzellik kazandırmaya, kendimizi kendimiz vasıtasıyla dönüştürmeye, kendimizi bir sanat eseri gibi işlemeye davet eder. ${ }^{48}$

Deleuze ve Guattari de, tıpkı Foucault gibi, metafiziğin aşılmasını, Evrensel'den, Tüm'den, Bir'den, Özne'den vazgeçilmesini sevinçle karşılamış ve özne olarak değil, bir sanat yapıtı olarak varoluş fikrini alkışlamıştır. Önemli olan, modern özne söyleminin bireyler üzerindeki tahakkümünden, köklerden, birliklerden, temellerden, baskıcı temsillerden kurtulmak ve arzunun özgürce akışına izin verecek yeni yaşam olanaklarının ve farklılıkların icadına kapı aralamaktır. Diğer bir deyişle, önemli olan, estetik temelli varoluş tarzları icat edebilmektir, "bilgi onların içine sızmaya ve iktidar onları kendine mal etmeye çalışsa da, hem bilgiden kaçabilecek hem iktidara direnebilecek isteğe bağlı kurallar uyarınca." ${ }^{49}$ Bunun için, bilinçdışı tarafından yaratılan, devrimci karaktere sahip, merkezsiz, bölük pörçük, dinamik, çok katlı bağlantılar tesis edebilen, üretken enerji akışlarıyla işleyen arzunun, onun akışlarını donduran ve istikrarlı hale getiren ve böylelikle yaratıcı enerjilerin önüne set çeken, onu

45 Madan Sarup, Post-Yapisalcllk ve Postmodernizm, s. 112.

46 Madan Sarup, a.g.e., s. 112.

47 Michel Foucault, Özne ve İktidar, s. 63, 68.

48 Michel Foucault, a.g.e., s. 262-266; Steven Best ve Douglas Kellner, Postmodern Teori, s. 81-93.

49 Gilles Deleuze, Müzakereler, çev. İnci Uysal, Norgunk Yayıncılık, İstanbul 2006, s. 107. 
evcilleştiren ve bastıran, ona kapalı yapılar içerisinde yer yurt edindiren baskıcı, kodlayıcı ve dayatmacı rasyonalist temsil ve yorum şemalarından, kapitalist toplumsal biçimlendirmelerden, modernliğin normalleştirilmiş öznelliklerinden kurtarılması ve özgürleştirilmesi gerekmektedir. Yani, postmodern bir özgürleşme, arzunun zincirlerinin kırılmasına, modern toplumsallığın, bilgi ve iktidarın kısıtlayıcı ve yer yurt edindirici güçlerinin boyunduruğundan kurtulmasına ve böylece yersiz yurtsuzlaşmaya bağlıdır. Bu, şizofrenik bir süreçtir. Bu yüzdendir ki, Deleuze ve Guattari, arzunun zincirlerini kırarak onu tekrar akışkan ve yaratıcı haline döndüren, modern öznelliğe, kapitalist gerçekliğe ve bütün normalleştirmelere meydan okuyan, mutlak kodları kıran, özgürleştiren ve özgürleşmiş varoluş tarzlarını yaratan, kapitalizmin yok edici meleği şizofreniğe ya da şizo-özneye büyük bir önem atfeder..$^{50}$

Derrida da kendini evrensel, mutlak, zorunlu hakikatin ayrıcalıklı temsilcisi, tektipleştirici ve her şeyin efendisi gören kendi kendine yeter Özneyi yıkmaya çalışanlardandır. Derrida'nın yapıbozumu (dekonstrüksiyon), gerçekliğe dolaysız ulaşmanın, mutlak ve kesin bir bilgiye temel aramanın, mütekabiliyetçi doğruluk kuramının, bir başlangıç ve merkez fikrinin, sabit ve evrensel bir öznenin, mutlak temeller ve ilk ilkelerin, dilden bağımsız saf bir anlam ve hakikat düzeninin olanaksızlığını dile getirir. Derrida, Batı düşüncesini, gerçeğin yapısının ve bu gerçeğe ilişkin dolaysız kesinliğin ve doğrunun akılda var olduğunu imleyen - ki bu, sözmerkezcilik ya da logosmerkezciliktir - bir 'bulunuş metafiziği' olarak niteler. Burada bütün inançlarımızın temelini oluşturan bir öz ya da doğruluğun varlığı, bir dayanak, bir ilk ilke söz konusudur. Ve Batı metafiziğinin madde, idea, akıl, öz, Tanrı gibi ayrıcalıklı ve egemen dayanakları ve ilk ilkeleri birer "bulunuş" terimleridir. Bu ilk ilkeler/egemen terimler hep dışladıklarıyla, diğer terimlere dair oluşturulan karşıtlıklarla tanımlanırlar. Bu dayanaklar ve ilk ilkeler, anlamı, kesinliği ve doğruluğu kendinden menkul olup diğer bütün terimlerin kendisine tabi olduğu ve kendi çevresinde döndüğü hiyerarşik bir düşünce sistemi oluşturur. Bu hiyerarşik yapının ayırt edici özelliği ise, egemen bir terimin başka bir terimi kendi karşıtı olarak kurması ve bir öteki olarak olumsuzlamasıdır. Sözün yazıyı,

50 Steven Best ve Douglas Kellner, Postmodern Teori, s. 110-132. 
aklın duyguyu, erkeğin kadını olumsuzlayarak kendisini kurması gibi. ${ }^{51}$

Derrida öncelikle, dilin içine gömülü olduğumuza, bir başka ifadeyle dilin varlığın evi olduğuna ve dolayısıyla gerçeklik denen şeye dolaysız bir nüfuzun mümkün olmadığına işaret eder. Öyleyse dilin dışına çıkarak ya da dilin dolayımından kurtularak gerçekliğin kalbine inmemiz ve mutlak, zorunlu ve evrensel bir hakikat, saf bir anlam ve kimlik keşfetmemiz bir yanılsamadır. Derrida topyekün hayatı, sonsuzca yorumlanmaya açık ve hiçbir yorumun diğeriyle mukayese edilemeyeceği ucu açık bir metin olarak görür. Bir metnin anlamı ise, saf bir hakikat düzenine referansta veya kendiyle özdeşliğinde değil, metnin bizi başka metinlere göndermesiyle oluşan dilsel eğretilemelerdedir. Anlam olgusal gerçekliğe tekabüliyette ya da saf bir kendilikte değil dilsel eğretilemelerde ise bu, anlamın sürekli elimizden kaçtığına, sürekli farklılaştığına ve sonsuzca ertelendiğine ve karar verilemez olanda ikamet ettiğine delalet eder. ${ }^{52}$

Derrida'nın yapıbozumunun amacı ise, idea/madde, ruh/beden, söz/yazı, kültür/doğa, erkek/kadın, rasyonel/irrasyonel, akıl/duygu gibi ikili karşıtlıklar üzerine oturan Batı metafiziğinin ipliğini pazara çıkarmaktır. Batı Metafiziği, ikili karşıtlıkları oluşturan terimlerden birisine pozitif, ayrıcalıklı ve egemen bir konum tahsis ederken ayrıcalıklı terimin, değersizleştirdiği, ötekileştirdiği karşıtına olan bağımlılığını gizlemiş ve inkar etmiştir. Yapıbozumu, ötekileştirilen ve değersizleştirilen terimin, ayrıcalıklı terimin varlığının ve kimliğinin zorunlu ve özsel bir parçası olduğunu, ona anlamını veren şey olduğunu gözler önüne serer. Derrida yapıbozumuyla, bir metindeki hakim ve ayrıcalıklı terimin tahrif ettiği, değersizleştirdiği, gizlediği ve bastırdığı şeyi, yani o terimin olumsuzladığı karşıtını ortaya çıkarıp, tersine çevirme işlemiyle, değersizleştirilmiş terimi ayrıcalıklı terimin yerine koymak suretiyle yeniden değer kazanmasını sağlar ve söz konusu ikiliğin yapısını bozuma uğratır. Sonrasında, yerinden oynatma işlemiyle de, değersizleştirilmiş ve ötekileştirilmiş terimin ayrıcalıklı ve egemen terimin varlığı ve kimliğinin zorunlu bir parçası olduğunu, ayrıcalıklı terimin farklı bir terimi bastırmadan, değersizleştirmeden ve olumsuzlamadan kendi varlığını, kimliğini, bütünlüğünü ve ayrıcalığını tesis edemeyeceğini göstermek amacıyla, değersizleştirilen terimi

51 Jacques Derrida, Gramatoloji, çev. İsmet Birkan, Bilgesu Yayınları, Ankara 2010, s. 20-24, 86-87, 100-101, 108, 477.

52 Madan Sarup, Post-Yapisalcllik ve Postmodernizm, s. 70-82 
ayrıcalıklı terimin merkezine yerleştirir. Kısacası, yapıbozumuyla başarılan şey, karşıtlıklarda ayrıcalıklı olanın yerine değersizleştirileni, sözgelimi rasyonelin yerine irrasyoneli geçirmek değil, karşıtların kopmaz biçimde birbirine bağımlı olduklarını, birbirlerinin içine girdiklerini ve birbirlerinde içerildiklerini, nihai bir sentez ya da birlik kurmaksızın ayrılmaz olduklarını göstermek ve böylelikle karar verilemezin deneyimiyle özgürlüğe, farklılığa, çoğulculuğa, etik ve siyasi sorumluluğa kapı aralamaktır. "Karar-verilemezlik, kararı mesken tutmaya devam eder ve karar kendini karar-verilemezliğe kapatmaz." 53 Ve Derrida bizi tam bir paradoksun içine sürükler ama özgürlüğe, sorumluğa ve karara imkan veren bir paradoks: Karşıtlıkları oluşturan terimlerden her biri diğerinin hem imkanıdır hem de imkansızlığıdır. Bir başka deyişle, bir imkanı kendi imkansızlığı olarak tanımlamak. Dolayısıyla karar verilemezlik, katedilebilecek ve alt edilebilecek bir şey değildir. Bu yüzden sağlam bir temele dayandığ ve kendi kendini garantilediği iddia edilen bir karar karşısında, "Bana tek bir kod, tek bir dil oyunu, tek bir bağlam, tek bir durum tahsis edecek bir söylemi kesinlikle reddediyorum; ve bu hakka kapris olsun diye ya da böylesi hoşuma gittiği için değil, etik ve siyasi nedenlerle sahip çıkıyorum" der. ${ }^{54}$

Karar verilemezin deneyimi olarak yapıbozumu düşüncesiyle Derrida'nın modern özne fikrine; dilin, yorumun, arzunun dolayımından azade gerçekliğe doğrudan nüfuz kabiliyetine sahip, kendi anlamını mutlak bir biçimde kendisine referansla tesis edebilen bir özne fikrine neden sıcak bakmadığı aşikardır. En önemli gerekçe, etik ve siyasi özgürlük ve sorumluluktur. Çünkü modern özne, kendi kimliğini özgür bir konsensüs, aklın gerektirdikleri veya doğanın zorunlulukları - töz ve Tanrı fikri de dahil olmak üzere - temelinde kurma ve sabitleştirme eğilimindedir. Böylelikle oluşturulan güçlü kimlik "bir dizi farklılığı doğası itibariyle kötü, akıldışı, anormal, deli, hasta, ilkel, canavar, tehlikeli ya da anarşik yani öteki - olarak kurmaya çalışacaktır. Bunu kendini doğası itibariyle iyi, tutarl, tam ve rasyonel olarak güvenceye almak ve eğer meşruluk kazanacak olursa kesinliğini ve insanları kolektif eyleme geçirme gücünü çözecek olan ötekinden kendini korumak için ya-

53 Jacques Derrida, "Yapıbozum ve Pragmatizm Üzerine Düşünceler", Yapıbozum ve Pragmatizm, C. Mouffe (der.), çev. Tuncay Birkan, Sarmal Yayınevi, İstanbul 1998, s. 140.

54 Jacques Derrida, "Yapıbozum ve Pragmatizm Üzerine Düşünceler", a.g.e, s. 131. 
par. Böylece oluşturulan ötekiler grubu artık güçlü kimliğin doğruluğu için hem çok önemli hem de tehditkar hale gelir. Eğer kimliğimi özünde seçilmiş ya da derin kimlik olarak görürsem, sizin de bu özellikleri bir dereceye kadar paylaşmanızı isterim. Burada sizin davranış tarzınızdaki farklılıkları kötü niyet, yanlış bilinç, masumiyet, sapma, hastalık ve kötülük kategorileri yardımıyla yorumlama yönünde güçlü bir baskı vardır. Modern birey [tabi ki kimliğini Tanrısallık temeline yaslayan dindar birey de] kendi kimliğinde insanlık durumuna karşı bir hınç taşır ve bu en net biçimde o kimlikten önemli ölçüde sapanlara karşı gösterdiği hıncın yoğunluğunda açığa çıkar. Zira bu sapmalar çoğaldıkları takdirde kendi kimliğiyle özdeşleşmiş benliğin kendini bu biçimde koruması için gereken disiplini ve kısıtlamaları kabul etmesi yüzünden enayi gibi görünmesine yol açarlar. Kişinin özsorumluluk standardı yüzünden başına açılan dertlere karşı duyduğu hınç, o standardın buyruklarından kaçtıklarını düşündüğü insanlara karşı beslediği bir kin haline gelir." 55 Oysa Derrida'nın bizlere öğrettiği üzere, irrasyoneli, duyguyu, dini, yereli, geleneği, farklılıkları dışlayarak, değersizleştirerek ve ötekileştirerek kendi kimliğini kuran modern özne, değersizleştirdiklerinin kendi kimliğinin kurucu ve merkezi ögeleri olduğunu, varlığı ve kimliği açısından değersizleştirdiklerine bağımlı olduğunu, aslında değersizleştirdiklerini kendi kimliğinin tam kalbinde ihtiva ettiğini gizleyen bir büyücü gibidir.

Açıkça görüleceği üzere, gerçekliğe veya herhangi bir temele atıfla temellendirilen söylemler doğası itibariyle farklılılıkları, karşıt ve muhalif inançları bastırma eğilimindedir. Kesinlik ve temel arayışı pek de masum bir şey değildir bu nedenle. Çünkü bu duygu ve eğilim, otoriter ve baskıcı kişiliklerin üretilmesine yardım eder ve faşist ve hegemonyacı yönetimler için verimli ve meşru bir zemin hazırlar. ${ }^{56} \mathrm{Bu}$ yüzden, karar verilemezlik ve temelsizlik, özgürlüğe imkan açabilmek, farklılıkların serpilmesini sağlamak ve sorumluluğu tesis edebilmek açısından son derece önemlidir Derrida için. Ve tabi ki postmoden düşünce için de. Aksi halde hem etiğin hem de çoğulcu demokratik bir siyasetin çöküşüne tanıklık ederiz. Derrida'nın sözleriyle, "sorumluluk, yalnızca farklı ve birbirine uymayan iki yasağa cevap vermemi gerektiren bu çatışkılı yapılar varolduğu için vardır. Sorumluluk bu noktada başlar, ne yapmam

55 Willim E. Connolly, Kimlik ve Farklılık, çev. Ferma Lekesizalın, Ayrıntı Yayınları, İstanbul 1995, s. 94, 112, 157.

56 Steven Best ve Douglas Kellner, Postmodern Teori, s. 279. 

gerektiğini bilmediğim noktada. Ne yapmam gerektiğini bilseydim, kuralı uygulardım. Etik, ne yapman gerektiğini bilmediğin noktada, bilgiyle eylem arasında bir uçurum olduğunda, var olmayan yeni kuralı icat etmek için sorumluluk üstlenmen gerektiğinde ortaya çıkar. Garantileri olan bir etik, etik değildir. Sorumluluk üstlenmek ya da bir karar almak çılgınlıktır, çünkü ancak birbiriyle rekabet eden, çatışan iki yasak, iki emir varsa bunu yaparsınız." ${ }^{57}$ Dolayısıyla, Deleuze ve Guattari'nin de dediği gibi, hakikat "önceden varolan ve keşfedilmesi gereken bir şey değil de, her alanda yaratılması gereken bir şey"dir. ${ }^{88}$ Hakikatin bireysel olarak yaratılan bir şey olması da, farklılığın, kararın, sorumluluğun ve özgürlügün imkanıdır.

Postyapisalcılıktan kendisini artık bir postmodernist olarak niteleyen düşünürlere geçtiğimizde dikkati çeken en önemli nokta, farklılık ve özgürlük nidalarının daha güçlü işitiliyor olmasıdır. Bunun için de, evrensel ve kendi kendine yeter bir öznenin merkezden alınıp alaşağı edilmesine, dilin, tarihin, benliğin/kimliğin olumsallığının gösterilmesine, dil oyunlarının ve rasyonelliklerin çoğulluğunun ilan edilmesine, temellerin, dolaysız kesinliklerin, uzlaşımların, evrensellerin yıkılmasına ve farklı dillerin yarattığı bir çoğul hakikat evreninin inşa edilmesine ihtiyaç vardır. Nitekim Postmodern Durum'un yazarı Lyotard farklılıkları, çeşitliliği, çoğulluğu ve yeniliği korumak adına, hakikat, ilerleme, özgürleşme ve refah temalarıyla ve iddialarıyla kendisini meşrulaştıran büyük anlatılara özellikle Aydınlanmanın büyük ideallerine ve öznesine-, temelciliğe, evrenselciliğe, uzlaşıma, bütünleyici ve birlikçi düşüncelere şiddetle karşı durur. Farklılıkları koruyabilmek için de yöntem olarak Wittgenstein'ın dil oyunları görüşüne müracaat eder. ${ }^{59}$ Çünkü gerçekte bilgi uzlaşmalarla değil, ancak farklılıklar arasında cereyan eden tartışmalarla, çekişmelerle, anlaşmazlıklarla ve yeni paradigmalar icat etmekle geliştirilebilir. Bir tarafın meşruluğu diğer tarafın meşruluktan yoksun olduğu anlamına gelmez, zira bütün dil oyunlarının üstünde duran bir hakikat ölçüsü, bir meta dil, bir evrensellik yoktur. Aksi halde uzlaşım ve evrensellik, dil oyunlarının heterojenliğini ve birbirleriyle kıyaslanamazlığını çiğner ve bilginin

\footnotetext{
57 J. Derrida, F. Kermode, T. Moi, C. Norris, Teoriden Sonra Hayat, M. Payne ve J. Schad (der.), çev. Ebru Kılıç, Agora Kitaplığı, İstanbul 2004, s. 33, 37.

Gilles Deleuze, Müzakereler, s. 143.

59 Jean-François Lyotard, Postmodern Durum, çev. Ahmet Çiğdem, Ara Yayıncılık, İstanbul 1990, s. 24, 53-55.
} 
icadı için gereken çekişme ve anlaşmazlığ 1 da ortadan kaldırmış olur. Lyotard'ın gözünde modası geçmiş ve şüpheli bir değer olarak uzlaşım ve evrensellik, dil oyunlarının farklılığını ve kıyaslanamazlığını bozarak bir tür terör yaratır. ${ }^{60} \mathrm{Bu}$ yüzden Lyotard, farklılıkların korunması ve özgürlügün yeşertilebilmesi adına bir rasyonaliteler ve akıllar çokluğuna göndermede bulunur. ${ }^{61}$ Ve yine bu yüzden, evrensel bir uzlaşım temelinde evrensel bir özne ve birlik hayalinin peşindeki Aydınlanmacı Habermas'ın çabalarını hiç basiretli bulmaz. Lyotard eserinin sonunda bizlere şu çağrıda bulunur: "Gelin bütünlüğe karşı bir savaş başlatalım, gelin sunulamayana [yani, tüm uzlaşımlara direnene] tanıklık edelim, farklılıkları etkin kılıp, adın onurunu kurtaralım."62

Sıkı bir postmodernizm savunucusu olan Bauman'ın eserlerinde de, tıpkı Lyotard'da olduğu gibi, farklılıkların serpilmesi ve özgürleşme adına modernizme karşı savaş veren hassas bir ruhla karşılaşırız. $\mathrm{O}$, postmodern zihniyetin yeni değerleri olan özgürlük, farkl1lık ve hoşgörünün sözcülügünü yapan etkili bir düşünürdür. ${ }^{63}$ Onun gözünde modernlik, varoluşun tasarım, manipülasyon, yönetim ve mühendisliğin etkisi altında olduğu ve bunlar tarafından sürdürüldügü bir düzendir. Modernliğin köklerinde, yasakoyucu ve tahakkümcü bir aklın düzen sağlama güdüsü vardır. Modern akıl müphemliğin, olumsallığın ve belirsizliğin kökünü kazımak için tanımlama ve sinıflama yoluyla dünyayı ve hayatı biçimlendirmeye ve ona düzen vermeye girişir. Bu yüzden tanımlanamazlık, tutarsızlık, uyumsuzluk, bağdaşmazlık, mantıksızlık, irrasyonellik, ikircim, karar, kararlaştırılamazlık, müphemlik ve belirsizlik,düzenin düşmanı olan yabancılardır. Evrensel ve doğal bir temele dayandırılan bilimsel ve rasyonel düzen inşası, bu inşa katılma ve kabul edilmenin de sınırlarını çizdiği için, tanımlanamayanı, irrasyoneli, müphem olanı, düzene uyumsuz olanı yabancı, düşman, öteki, aşağılık, sapkın, ilkel, gerici vb. sıfatlarla değersizleştirir ve ona bir kimlik, herhangi bir hak ve yaşama şansı verilmesini reddeder. Çünkü o, düzen için risktir, tehdittir; o, düzenlenmiş bakımlı bir bahçenin kökünden sökülüp atılması gereken yaban otudur. Bu yüzden modern

\footnotetext{
60 Jean-François Lyotard, Postmodern Durum, s. 77-85

61 Barry Smart, "Postmodern Toplum Teorisi", Modernite versus Postmodernite, Mehmet Küçük (der.), Vadi Yayınları, Ankara 2000, s. 336-337.

62 Jean-François Lyotard, Postmodern Durum, s. 98.

63 Zygmunt Bauman, Modernlik ve Müphemlik, s. 349.
} 
akıl hoşgörüsüzdür; sürekli gözetleyici, denetleyici ve disipline edicidir. Modern aklın ötekisi yabancı, müphemlikle sürekli hemhaldir, niteliksizdir, doğal ve verili bir kimlikten yoksundur, kendisini evinde hissedeceği bir yurdu yoktur, köksüzdür. Ve köksüzlük, temelsizlik kesin olan her şeyi göreceleştirir; aklın otoritesine karşı bir meydan okumadır. Bu nedenle, yabanc1, asimilasyonla bile düzeltilemeyecek denli uygunsuz varoluşsal yapıya sahiptir. Ne var ki düzen takıntılı modernlik projesi zamanla insani varoluşsal imkanların ve potansiyellerin acımasızca budanmasına, etik hiçbir sorumluğu bulunmayan rasyonel ve bilimsel soykırımların, katliamların, infazların, sömürülerin tasarlanarak icra edilmesine yönelmiş ve despotik yönetimlere, geleceğe dair güvenlik ve sigorta kaygısının ve evrensel birlik ve iyimserlik düşüncesinin neticesi olarak özgürlük yitimine, daha fazla gözetleme ve disipline, daha fazla müdahale ve tasarıma yol açmıştır. Dahası, çağdaş toplumdaki aşırı işbölümü ve alanların işlevlerine göre ayrılmasıyla birlikte köksüzlük ve yabancılık tüm bireylerin ortak kaderi olmuştur. Çağdaş birey artık büyük ölçüde farklı ve hatta çelişkili toplumsal dünyalardan örülü bir yaşamın içinde bulmuştur kendisini. Ne yazık ki çağdaş birey, bu toplumsal dünyalardan hiçbirisinde kendisini evindeymiş gibi hissedememektedir artık. Çağdaş birey, evrensel yabancıdır bundan böyle. Bir zamanlar cemaatlerin uhdesindeki kimlik üretme işi bireyin omuzlarına yüklenmiştir. Kısacası modernlik, zamanla evsizlik ve aidiyetsizlik haline dönüşmüştür. Bugünün dünyası, yabancılığ ve buna sinen varoluşsal müphemliği yok edememektedir. Bir anlamda, yabancılık evrenselleşmiştir. Ve herkes yabancı ise hiç kimse yabancı değildir. Bauman'a göre postmodernizm, bu nedenle, kendi imkansızlığıyla yüzleşen ve uzlaşan modernliktir. Büyük toplumsal tasarılara duyulan nefret, mutlak hakikatlere duyulan ilgi kaybı, bütün yaşam tekniklerinin göreceli değeriyle uzlaşma, dünyanın iflah olmaz çoğulluğu ve belirsizliğinin kabulü anlamındaki postmodern düşünce, Bauman'a göre kayg1 verici görünse de renklidir, heyecan vericidir, özgürleştiricidir ve gerçek bir hoşgörünün mimarıdır. Bauman'ın sözleriyle, "postmodernlik, müphemliğin üstesinden gelmeyi ve aynılı̆̆ın tekanlamlı kesinliğini hedefleyen tipik modern güdüden tamamen özgürleşme anlamına gelir. İdeal anlamda, postmodernliğin çoğul ve çoğulcu dünyasında, ilke olarak bütün yaşam biçimlerine izin veriliyor; ya da daha doğrusu, hiçbir yaşam biçimi, herhangi bir yaşam biçimini izinsiz kılacak kadar bariz (ya da tartı̧̧masız) değildir. Farklılık bir baskı olmaktan çıkıp, eylem ve çözüm gerektiren bir sorun olarak 
algılanmadığı zaman, farklı yaşam biçimlerinin barış içinde birlikte yaşamaları, düşman güçlerin geçici bir dengesi olmaktan başka bir anlamda mümkün hale geliyor. Bir yandan birlikte yaşama ilkesi, evrenselleştirme ilkesinin yerini alabilirken (sadece -abilirken), öte yandan hoşgörü önermesi ihtida ve tabiiyet önermelerinin yerine geçebilir (sadece -ebilir). Özgürlük, eşitlik ve kardeşlik, modernliğin sloganıydı. Özgürlük, farklılık ve hoşgörü ise postmodernliğin ateşkes formülüdür." 64

Bauman'ın doğal veya verilmiş bir kimliği olmayan, müphemlik, belirsizlik, irrasyonellikle ve uyumsuzlukla sıkı fıkı yabancisı, açıkça görüleceği üzere, Aydınlanmanın rasyonel ve evrensel öznesine meydan okuyan ve hatta onu kendi imkansızlığıyla yüzleştiren bir karaktere sahiptir. Tipkı Foucault ve Deleuze gibi, Bauman da bireyin, iktidarın, düzenin, toplumsal ve kültürel koşulların büsbütün esiri olduğuna, yani tamamen yaratılmış olduğuna inanmaz. $\mathrm{O}$, bireyin kendi özgür ve özerk seçimleriyle kendisini - kendi toplumsallığ1 içerisinde bulabildiği hazır malzemelerle - olumsal karakterde inşa edebileceğine ve bu yüzden özgürlüğe mahkum olduğuna inanan iyimser bir postmodernisttir. İçinde yaşadığımız çağda insanlar birbiriyle rekabet eden birçok iyi hayat anlayışının, geleneğin, cemaatin, grupların sınırlarında gidip gelmektedir. Bunlardan hiçbirisi toplumda en üst ve hakim konumu ve otoriteyi elde edebilecek lükse sahip değildir. Dolayısıyla insanlar çok merkezli, çok ağlı ve çok katmanlı bir toplumun içerisinde yer almaktadırlar ve bu koşullar içerisinde kendi yüzergezer kimliklerini oluşturmak zorundadırlar. Oysa modern toplum öncesinin büyük gelenekleri ve cemaatlerinin üyesi olan insanların kendi kimliklerini oluşturma gibi bir sıkıntıları, risk ve belirsizliklerle mücadele etme gibi bir kaygıları yoktur. İnsan bütünlüklü ve sabit bir kimliğin temeli olan geleneğin içine doğmakla doğal olarak kimliklenmiş olur ve kendisini tamamen güvenli bir limanın sakini olarak bulur, böylelikle de risk ve belirsizliklerin yakasını asla bırakmayacağı, onu tam bir varoluşsal güvensizliğin içine gömecek ve özgürlüğe mahkum edecek bir kendini seçme ve yaratma yükünden kurtulmuş olur. Özgürlük ve özerkliğe vurgusuyla modernizm geleneği yıktığı ve insanları birbiriyle yarışan iyi hayat anlayışlarının tam ortasına bıraktığı için bugünün insanı açısından aidiyet - varoluşsal belirsizlik, güvensizlik ve emniyetsizliğin giderilmesi - en önemli sorun olarak kendisini 
göstermiştir. Kimliğin hiçbir sabit temeli ve dışsal garantisi olmaması nedeniyle, yapılan seçimler konusunda pişmanlıklar, belirsizlikler, kararsızlıklar daimidir. Kendisini böyle bir belirsizlik ve emniyetsizlik içerisinde bulan modern çağın insanını Bauman, Gellner'den alınma bir metaforla, "modüler insan" olarak tanımlar. Eski ve yeni insan tipi arasındaki fark, tek parçalı, tamamlanmış bir gardırop ile modüler bir gardırop arasındaki farkla izah edilir. "Nasıl ki modüler mobilyanın önceden tasarlanmış tek bir 'uygun' biçimi yoksa, alabileceği olası biçimler sonsuzca genişleyebiliyorsa, modüler insanın da önceden belirlenmiş bir profili ve kararlaştırılmışlı̆̆ yoktur. Modüler insan, öncelikle, özü olmayan insandır. Ancak modüler mobilyanın tersine, modüler insan birleştirme ve dağıtma işini kendisi yapmaktadır. O modüler insan olduğu kadar kendi modelini de çizen insandır.. Modüller arasındaki bütünleşme zayıf; her türlü birliktelik biçimi yaralanmaya açık ve kırılgan. Hiçbir grupta kendimizi 'tamamen evimizde' hissetmiyoruz. Demek ki 'modülerlik' durumu bir Unsicherheit durumudur; yani üçlü belirsizlik, güvensizlik ve emniyetsizlik felaketi durumu. Ama sürekli bir gerilim kaynağı olan şey modülerliğin kendisi - modülleri daimi bir şekle sokacak vidaların, cıvataların, perçinlerin olmayışı." 65

Açıkça görüleceği üzere, Bauman, postmodernliğin değerleri olan farklılık, özgürlük ve hoşgörünün ancak Modern özneyi yok etmekle, bu öznenin rasyonellik, evrensellik, bilimsellik, mantıksallık gibi silahlarını zayıflatmakla ve yine bu öznenin kurduğu toplumsal düzeni yıkmakla tesis edilebileceğine inanmaktadır. Bu yapılmadığı takdirde, farklılık, özgürlük ve hoşgörü şansını elimizden kaçırmış; şiddeti, dışlamayı, katliamı, terörü hep meşrulaştırmış oluruz. Nitekim "Tarih, bir ve tek hakikat adına işlenen cinayetlerle doludur. Ancak çoğulluk ve hoşgörü adına işlenen tek bir zalim eylem örneğine işaret etmek zordur. ... tek parti, tek tarih hükmü, tek ilerleme çizgisi, insan olmanın tek yolu, tek (bilimsel) ideoloji, tek doğru anlam, tek doğru felsefe. Bütün bu bağlamlarda 'bir ve tek ibaresi' bir ve tek mesaj taşıyor: bazıları için iktidarı tekellerinde bulundurma hakkı ve ötekiler için tam itaat yükümlülügü." 66 Oysa bir metnin sonsuz sayıda anlaşılabileceğine ve yorumlanabileceğine inanan insanlar müzakereye açık hale gelirler

65 Zygmunt Bauman, Siyaset Arayışı, çev. Tuncay Birkan, Metis Yayınları, İstanbul 2000, s. 166-170.

66 Zygmunt Bauman, Postmodernlik ve Hoşnutsuzlukları, s. 285-286. 
ve birbirlerini öldürme gereği duymazlar. Sırf özgürlük, sorumluluk ve farklılık gerekçesiyle Bauman, tıpkı Lyotard gibi, evrensellik peşinde koşan Aydınlanmacı Habermas'ı şiddetle eleştirir ve evrensel uzlaşım ve konsensüsü, özgürlük ve farklılığın son nefeslerini verdikleri mezarlık olarak niteler. ${ }^{67}$

Postmodernliği 'kırıntılarla oynamak' diye niteleyen Baudrillard ise tarihin, toplumsalın, teorinin, anlamın, gerçekliğin, öznenin, iktidarın, bilimin, üniversitelerin sonunu ilan eden bir felaket tellalı kötümser olarak anılır hep. Ona göre bugün insanlar, simülasyonların egemenliği altında oldukları bir tarihsel evrede yaşamaktadırlar. Bir şeyi simüle etmek, sahip olunmayan bir şeye sahipmiş gibi yapmaktır. Simülasyonlar gerçeği sürekli yeniden üreten, gerçeğin yerini alan ve hatta gerçekten daha fazla gerçekliğe (hipergerçek) sahip olan modellerdir. Bunların bir olgular ve nedenler mantığıyla hiçbir ilişkisi olmadığı gibi herhangi bir göndereni de yoktur. Göndereni tersyüz eder ve öldürürler çünkü bunların gerçekliğin hiçbir çeşidiyle ilişkisi yoktur. Dolayısıyla bunlar, gerçekliğin temsili veya yeniden canlandırması olmayıp gerçeğin değil yalnızca kendi kendisinin yerine geçen sanallıklardır. Sözgelimi, uzay ve nükleer alana ait modeller yalnizca birer simülasyondurlar ve evrensel bir denetleme sistemine ait olup hiçbir şeyi rastlantıya bırakmayacak bir toplumsal kusursuzluğa modellik yapan teknik kusursuzluğun ifadesidirler. ${ }^{68}$ "Çünkü günümüzdeki temel strateji sonsuza dek sürdürülmeye çalışılacak bir felaket simülasyonu aracılığıyla zihinsel bir terör yaratma ve caydırma düşüncesi üzerine kuruluysa, bu senaryoyu gizleyebilmenin tek yolu bir felaket yaratmak, gerçek bir felaket üretmek ya da yeniden üretmektir. Zaman zaman doğa da böyle yapmaktadır. Zaman zaman Tanrı da bu türden doğal felaketler yaratarak insanları içinde bulundukları bu terör düzeninden geçici olarak kurtarmaktadır." 69 İşte bu yüzden simülasyon gerçekten her zaman daha etkilidir. Ve bizler medyanın yarattığı, sürekli yeniden ürettiği sanal bir gerçekliğin içerisinde yaşamaya mahkumuz artık. Olgusal gerçekliğin temsilcisi olduğuna inanılan bilim bile saf bir simülasyona dönüşmüştür. Ve ne yazık ki "gerçek bir daha asla geri dönmeyecektir."70

\footnotetext{
67 Zygmunt Bauman, Postmodernlik ve Hoşnutsuzluklarl, s. 287.

68 Jean Baudrillard, Simülakrlar ve Simülasyon, çev. Oğuz Adanır, Doğubatı Yayınlar1, Ankara 2008, s. 14-28, 35, 61-62, 66-67, 87

69 Jean Baudrillard, a.g.e., s. 88.

70 Jean Baudrillard, Simülakrlar ve Simülasyon, s. 15.
} 
Şayet gerçek dünyadan söz etmek, onu üretmek demekse ve bu anlamda gerçek, bir simülasyondan ibaretse, kendi başına gerçek diye bir şey yoktur. Simülasyonlar yoluyla gerçeklik, hakikat ve nesnellik duygusu başarılı ve etkili bir biçimde yaratılabilmektedir. Böyle bir simülasyonlar evreninde artık düşünen, eylemci bir özneye gerek yoktur. Çünkü her şey kusursuz bir biçimde üretilmektedir zaten. ${ }^{71}$ Ve kendisinin keşfedilmesine ve üzerinde egemenlik kurulmasına izin vermiş görünen edilgin nesne, özneden intikam alan bir tür hasma dönüşmüştür. Çünkü sanallaşarak, stratejik bir biçimde ortadan kaybolan ve bundan böyle kavranması mümkün olmayan nesne, ironik biçimde, gerçekliğin de öznenin de sonunu imlemektedir. ${ }^{72}$ Bu bir cinayettir. "Sanal teknolojisi aracilığıyla, sözcügün en genel anlamında bir kusursuzluk aşamasına ulaşılmakta ve bu aşama da bize bir şeylerin sonunu işaret etmektedir. Bundan böyle gidilecek ya da gelinecek bir yer yoktur. Kusursuz cinayet, ötekiliği, ötekini yok etmekte ve aynının aynısına egemenliğini getirmektedir."73 Böyle bir şey, zaten dünyayı yok etmek demektir. Birey zihinsel, kültürel, genetik ve biyolojik olarak klonlanarak sonsuz sayıda çoğaltılmıştır. Böylelikle yazgıdan mahrum bırakılmış, genetik ve kültürel olarak kodlanmış birey kendi kendini sonsuza dek üretecektir. Bu klonlama, kusursuz bir cinayetten başka bir şey değildir. Baudrillard, bu cinayetin cezasız kalmayacağını ve hatta kalmadığını düşünür. Nesne özneden intikamını almaktadır. Özne kusursuz bir biçimde dünyayı yarattığını düşünürken, şimdi dünya onu biçimlendirmeye başlamıştır. "Zira dil düşünen bir varlıktır. Yalnızca onun aracılığıyla düşünmemizi sağlamaz, aynı zamanda bizi yaratır ve bizim yerimize de düşünür". ${ }^{44}$ Dilin olumsal dünyasının yanında parçacık fiziği de bizi rastlantısal/belirsiz bir dünyanın içine itmektedir. Artık kendimizi rastlantısal, karmaşık, belirsizleşmiş ve tersine çevrilebilme özelliğine sahip bir dünya içerisinde bulmaktayız. Böyle bir dünyaya uygun düşünce de belirsizliği ilke edinen, hakikate gönderme yapmayan, anlama egemen olmayan bir düşünce olmak zorundadır. ${ }^{75}$

71 Jean Baudrillard, Anahtar Sözcükler, çev. O. Adanır ve L. Yıldırım, Paragraf Yayınları, Ankara 2005, s. 54.

72 Jean Baudrillard, Anahtar Sözcükler, s. 19, 66.

73 Jean Baudrillard, Anahtar Sözcükler, s. 76.

74 Jean Baudrillard, Anahtar Sözcükler, s. 14.

75 Jean Baudrillard, Anahtar Sözcükler, s. 64-66, 77, 97-100. 
Sonuç olarak, Baudrillard için postmodern düşünce, bundan böyle anlamdan ve hakikatten yoksun, teorilerin boşlukta gezinip kendilerini tükettiği, olanaklı tanımların olmadığı, her şeyin olup bittiği, tüm olanaklılıkların uç noktasına varıldığı, her şeyin kaynayarak ve içe çökerek infilak ettiği nihilistik bir evreni anlatır. Edebiyatta, siyasette, sanatta, felsefede vs. olanaklı biçimler ve işlevler tüketilmiştir. Kusursuzlaştırma her şeyin sonunu getirmiştir. Bu nedenle Baudrillard, her şeyin bitip tükendiği, aynının kusursuz ve sonsuz tekrarlarına mahkum olduğumuz, geleceği olmayan bir gelecekle, tam bir yok oluşla karşı karşıya olduğumuzu düşünür. Yapabileceğimiz tek şey kırıntılarla oynamak, yani üretilmiş ve tüketilmiş olanları yeniden birleştirmektir. ${ }^{76}$ Bununla birlikte Baudrillard, sanılanın ve iddia edilenin aksine, belli belirsiz bir umut da taşımaktadır. Çünkü postmodernizm, insanların bir zamanlar neşeyle yıktıkları ve şimdi ayakta kalabilmek için üzüntü içinde yeniden inşa etmeye çalıştıkları her şeyi, geçmiş kültürleri, sırları vs. geri getirme eğilimindedir. ${ }^{77} \mathrm{Bu}$, gerçekleşir mi bilinmez. Ancak Baudrillard, kendi yaklaşımını dile getirdiği Anahtar Sözcükler'in son pasajında, birçok postmodernistte tanıklık ettiğimiz, belirsizlikle hemhal olarak özgürleşme ve insanın onurunu kurtarma kaygısını açığa vurmaktadır $\mathrm{ki}$, bu son derece olumlu bir yaklaşımdır. “Ölümü, olumsuzluğu kesinlikle ortadan kaldırıp onlardan kurtulmak isteyen bir dünyada düşünce, bir felaket habercisi rolü oynamak, felaket oyununun bir kahramanı olmak ve kışkırtmak zorundadır. Ancak bu düşünce aynı zamanda insanca olmak, insan konusunda kaygılanmak ve bunun için de iyi ve kötü, insanca olan ve olmayanın nasıl ters yüz edilebileceğini bulmak durumundadır."78

Postmodernizmi besleyen köklerden kendilerini postmodernist olarak adlandıran düşünürlere kadar izlediğimiz yolda hem postmodern denen düşüncenin kendine özgülüklerini hem de öznenin arkeolojisini/tarihini sunmaya çalıştık. Ve şu açıkça ortaya çımıştır ki, postmodern bir dünyada kurucu/yaratıcı, eylem ve bilginin merkezi, kendi kendinin özgür nedeni, bütünlüklü, sağlam temellere sahip bir modern/rasyonel özneye yer yoktur. Özne tari-

76 Steven Best ve Douglas Kellner, Postmodern Teori, s. 160-167; Jean Baudrillard, Anahtar Sözcükler, s. 67-73.

77 Steven Best ve Douglas Kellner, Postmodern Teori, s. 159.

78 Jean Baudrillard, Anahtar Sözcükler, s. 103. 
hin, bilinçdışının, dilin vs. içine gömülmüş ve karanlıklara karışmıştır - ya da zaten böyleydi. Kusursuz ve her şeyin mutlak temeli Tanrının ölümüyle birlikte son nefesini vermiştir. Bununla birlikte, nesnenin özneden intikam alan güçlü bir hasım olduğuna ve öznenin bir simülasyonlar evreninde kaybolup gittiğine inanan Baudrillard'1 ve özneyi tamamen toplumsal ya da psikolojik determinizm kodesine tıkanları görmezden gelecek olursak, postmodern düşünürlerin olumsallık/temelsizlik olarak özgürlükten ve kişinin kendi seçimleri ve özsorumluluğuyla kendisini bir sanat eseri gibi işlemesi ve yaratması anlamında özerklik ve kendilikten beslenen bir bireyden vazgeçmediklerini söyleyebiliriz. Foucault'nun iktidara direnerek kendi varoluşuna ihtimam gösteren ve kendi yazgısının tayininde söz sahibi olan, farklı öznelliklerin çiçeklenmesini muştulayan öznesi, Deleuze'un şizofreni, Bauman'ın modüler insanı, Rorty'nin ironisti bunun alametleridir. Rosenau ile birlikte diyebiliriz ki, postmodern birey, gevşek ve esnektir, merkezsiz ve çok katlıdır, kırılgandır; duygulara ve içselliklere yöneliktir, otantik olmanın derdindedir, geçici ve belirsiz olanı tercih ettiğinden "yaşa ve yaşat" tavrı içerisindedir; planlanmış şeylere, genel kurallara, kapsayıcı normlara, hegemonyacı düşünce sistemlerine karşı duyduğu nefret nedeniyle kendiliğindeliğe, doğaçlamaya, arzuların anlık tatminine, farklılığa ve çeşitliliğe, sonsuzca yoruma açık ve sonsuzca yorumla yaratılabilen bir dünyaya meyleder ve bu yüzden geleneğe, antikalaşmış olana, egzotik olana, kutsal olana, sıradışı olana ve yerel olana merak duyar, farklılığı, özerkliği ve özgürlüğü budayan her türden kolektiviteye, cemaate, dine, geleneğe vs. karşı mesafeli durur. Kısaca, postmodern birey özgürleşmenin ve otantikliğin derdindedir. ${ }^{79}$

\section{Dinin Sonu mu?}

Postmodernizmin Tanriya yaklaşımı, dürüstçe ifade etmek gerekirse, ateistiktir. Neden? İyice düşünülürse, modernizm ile din arasinda her şeye rağmen bir kan bağı vardır: Muktedir Özne, ezeliebedi hakikat, varlığın mutlak ve evrensel temeli, insanlarda evrensel ve insanüstü değer ve ilkelerde ortaklık, birlik, düzen vb. Nietzsche'nin daha önce belirttiğimiz çok yerinde tespitiyle, bilim ve din mutlak hakikate ve temele olan inançlarındaki ortaklıkları nedeniyle müttefiktirler. Eğer savaşacaklarsa birlikte savaşırlar ve yazgıları ölümse birlikte ölürler. Nitekim Modern düşünce Tanrıyı

79 Pauline Marie Rosenau, Post-Modernizm ve Toplum Bilimleri, s. 87-89. 
ya evrenin dışında tutarak, bir başka ifadeyle emekliye ayırarak deistik bir fikre yapışmış, ya Tanrının yerine insanı koyarak veya tam tersi, insanı Tanrılaştırarak Onu insanın şahsında cisimleştirmiş, ya metafizik boyutunu askıya alarak veya devre dışı bırakarak dünyevi haz ve mutluluğun etkili bir aracı olarak insanların hizmetine sunmuş ya da hiç olmazsa, rasyonelliği ve bilimselliği kanıtlanabilir bir Tanryya, yani rasyonel ve bilimsel bir dile indirgenebilir bir Tanrıya izin vermiştir. Dikkat edilirse, Tanrı inancına yönelik tüm bu modern tutum ve yaklaşımlarda hala Tanrı varlığını korumaktadır. Modern ateistler bile Tanrı yok derken tanrısal aletlerle bu işi yapıyor ve Tanrının yokluğunu göstermeye çalışırken zımnen varlığını da itiraf etmiş oluyorlardı. Ya da Tanrının varlığı inkar ediliyor olsa da ruhu hala aramızda/içimizde dolaşıyordu. Nitekim empirik, değişken, kararsız ve kırılgan benliğimizin gerisinde yatan, deruni bir benlik ya da gerçek benlik arayışı, modern düşüncenin hala teolojik mirası kullandığının en açık göstergesidir.

Postmodernistlerin evrensellik, zorunluluk, mutlaklık, temelcilik, temsil, rasyonellik, nesnellik, uzlaşma, bilim vb. zırhına bürünmüş, Tanrı tahtındaki özneyi öldürmeleri, onunla birlikte Tanrının da ebediyen yokluğunu imlemektedir. Ve Tanrının ölümü, varlığın temeli ve zemini olarak inanılan, değişmez, kusursuz, aşkın, tözsel ve nihai varlık ve gerçekliği temsil eden, insanlığa dair bütüncül ve nihai bir planı olan, her şeyi bilen, her şeyi gözeten, yaratııı, insanlara mutlak doğrularını ve buyruklarını dikte edip cennet ümidi ve cehennem korkusuyla insanlara ve tarihe yön veren, hakikate, mutluluğa ve kurtuluşa dair bütüncül bir üst anlatı oluşturan dinin Tanrısının ölümü demektir. Zaman, mekan ve tarih ötesi, dil ve öznellik dışı, nihai bir Gerçeklik olarak Tanrının ölümü, Tanrıyla insanlar arasında ayrıcalıklı bir mevkie ve dile sahip olan ve ilahi hakikati ve gerçekliği temsil eden, tek ve mutlak hakikate referansla insanları tek bir çatı altında toplayan peygamberlerin de gereksizliğini imler ve hatta onları nefret edilesi figürlere dönüştürür. Postmodern düşüncede artık hiçbir din, kendisini dil dışı bir gerçekliğe, mutlak bir hakikate ve sabit bir anlama referansla meşrulaştıramaz ve üstünlük iddiasında bulunamaz. Dilin kendisi dışında bir gerçekliğinin olmaması ve gerçekliğin de sonsuzca yorumlarla ve metaforik bir dille inşa ediliyor olması, dini, herhangi bir aşkın varlığa, dil dışı bir gerçekliğe yaslanmayan, herhangi bir temelden, değişmez ve bütünlüklü bir anlamdan, mutlak, ezeli bir hakikatten, ilahi bir amaçtan 
yoksun bir metin statüsüne indirger. Bu ise dini, şah damarı kesilmiş, beyni boşaltılmış, kalbi ve organları paramparça edilmiş cansız cesede dönüştürmekten başka bir şey değildir. Bu, gerçekten Tanrının ölümüdür. Ve bu, çok sağlam, çok acımasız ve radikal bir ateizmdir. Dolayısıyla postmodern bir dinden bahsetmek oldukça çelişkilidir. Tanrısız bir dinden bahsetmek ne kadar mümkünse! Mümkünse bile, farklı dillerin yarattı̆̆ı, olumsallık ve belirsizlikle yoğrulmuş, sadece kişiler arası karşılaşma ve ilişkilerde gerçeklik kazanan ve daha çok sevgi, adalet, sorumluluk, iyilikseverlik, hoşgörü, farklılıkların serpilmesi gibi insani arzu ve özlemlerin yerini tutan, hazzı ve anlık doyumu artıran, özgürlüğe ve sonsuz yoruma sinırsızca cevaz veren ve nihayet "ne olsa gider"i meşrulaştıran Tanrılardan söz edilebilir ancak.

Postmodernizm, evrensel ve tözsel bir doğa/özne fikrini yıktığ 1 için, Tanrının yeryüzündeki halifesi olan, Tanrıdan bir nefes ve suret taşıyan insan figürünü de anlamsızlaştırmıştır. Postmodernizmle birlikte, "Bir ben var benden içeri" veya "Nefsini bilen Rabbini bilir" sözlerinde ifadesini bulan ve hemen her dinsel ve mistik gelenekte karşılaşılan evrensel ve ezeli/ebedi ilahi benlik/ruh inancı da anlamını ve önemini kaybeder. İnsanların/varlıkların özde birliğini anlatan bu inanç, farklılı̆̆a ve özgürlüğe bir tehdit olarak algilanır postmodernistlerce.

Ve yine, özgürlük ve farklılık adına öznenin öldürülmesi, mutlak hakikatin, temelin, istikrarlı anlamın, dışsal otorite ve gerçekliğin yıkılması, aşkın bir gerçeklikten, dilin ve tarihin ötesindeki evrensel ve sonsuz bir boyuttan seslenen, olmuş-olacak her şeyi önceden belirleyen ve böylelikle bireyin karar verme ve kendini özgürce inşa etme imkanını ve dolayısıyla varoluşsal sorumluluğunu da elinden alan bir Tanrının öldürülmesini gerektirir. Böyle bir Tanrı varsa insan köledir, bir hiçtir. İnsan adaleti, bilgiyi, gerçekliği ve ölümsüz yaşamı kendi başına bulmakta yeteneksiz olduğu için buna ancak vahiyle erişebilir. Tanrısal aklın, kusursuzluğun karşısında insani bir aklın bir değeri yoktur ve Tanrının adaleti önünde bir dünya adaleti olamaz. "Tanrı her şey olduğu için gerçek dünya ve insan hiçbir şeydir." ${ }^{80}$ İnsanın öz-yetersizliğini, günahkarlı̆̆ını vurgulayan, kurtuluşu ancak öte dünyada mümkün gören ve bu ne-

80 Mihail Bakunin, Tanr ve Devlet, çev. Mustafa Tüzel, Belge Yayınları, İstanbul 2013, s. 107 
denle bu dünyayı hakir gören, dünya nimetlerinden dilenildiği kadar ve sinırsızca yararlanılmasını engelleyen ve bir çeşit zühdü, çileciliği ve fedakarlığı öven bir dinin postmodern düşüncede yeri yoktur. Ve yine mutlak ve yanılmaz bir dille seslenen, insanları birlik çatısı altında toplayıp tektipleştiren, belirsizliği ve yorumu ortadan kaldıran, insanları tercihte bulunma ve kendilerini inşa etme sıkıntısından kurtaran, insanların özgürlüklerini ve özerkliklerini tamamen feshedip omuzlarından sorumluluk yükünü alan köktenci din, postmodern düşüncenin asla tahammül edemeyeceği bir dindir. Böyle bir din, hastalıklı, nevrotik bir tutumun ifadesidir, bir tür nekrofilidir. ${ }^{81}$

Peki, Bauman'ın "Postmodern akıl, modern bilimsel akıl tarafından itilip kakılan ya da sınır dışı edilen bu aileye [din] daimi bir oturma izni vermeyi kararlaştırmış bulunuyor" 82 sözünden ne anlamamız gerekiyor? Hani postmodernizm, özgürlük ve farklılık adına hiçbirine ayrıcalık ve üstünlük tanımadan tüm gelenekleri ve cemaatleri önemsiyor, aidiyeti önemli bir mesele addediyor ve büyülü bahçeyi diriltmeye çalışıyordu! Bu bir kandırmaca ve bir yanıltmadan başka bir şey değildir. Çünkü postmodern aklın izin verdiği din - izin veriyorlar ve lütfediyorlar sağolsunlar! - ancak tüyleri yolunmuş, kolu-kanadı kırılmış bir tavuğa benziyor - iştah kabartıcı ve yenmeye hazır. Yani, izin verilen din yalnızca sekülerleştirilmiş olandır. Nitekim Bauman, özgürlük ve özerkliği tehdit eden, belirsizliği yok eden tüm dişsal temellere ve otoritelere, dinlere, geleneklere karşı mesafelidir. ${ }^{83}$ Din, yalnızca, aşkın kaynağıyla olan bağları kesilip olumsallaştırıldığında ve insanların kendini gerçekleştirmelerinin, dünyevi bir vecde erişmelerinin, haz ve mutluluk artırımının bir aracı haline getirildiğinde, yani içkinleştirildiğinde makbuldür. Böyle bir araç haline getirildiğinde ise zaten Tanrıya ihtiyaç kalmamıştır. Çünkü bu görevi tüketim toplumunun insanları, uzmanları, yaşam koçları, kişisel gelişimcileri layıkıyla yerine getirebilmektedir. Kant'ın ahlak dininin Tanrısı, Dewey'in doğaüstü bir Tanrıyı ve vahyi dışta bırakarak ve böylece dinleri zayıflatarak yaratmaya çalıştı̆̆ı, hayatı kolaylaştırmanın, mutluluk ve hazzı artırmanın bir aracı olarak insanların hizmetine sunduğu

81 Zygmunt Bauman, Postmodernizm ve Hoşnutsuzluklarl, s. 239-264; Terry Eagleton, Kuramdan Sonra, s. 207-212.

82 Zygmunt Bauman, Postmodernizm ve Hoşnutsuzlukları, s. 234.

83 Zygmunt Bauman, Siyaset Arayışı, s. 90-98; Postmodernizm ve Hoşnutsuzlukları, s. 260-264.

114 
ahlakileştirilmiş ve estetikleştirilmiş Tanrısı bunun en güzel örnekleridir. Daha da güzel ve etkileyici bir örneği, Alain de Botton'un Ateistler İçin Din adlı eseridir. Zira o, postmodernistlerin dine karşı tavırlarının en açık ve samimi ifadesini sunar bizlere: “Tanrının var olmadığına inanmaktan hiç vazgeçmedim. Ancak dinle, onun doğaüstü içeriğini onaylamak zorunda kalmadan ilişki kurmanın bir yolu olabileceği düşüncesi sayesinde özgürleşmeyi başardım. Bu kadar çok şeyden vazgeçerek dinin, mantıklı olarak tüm insanlığa ait olması gereken deneyim alanlarını kendi egemenliğinde görmesine izin verdik; şimdi bu alanları yeniden seküler dünyanın içine almak için harekete geçmekten çekinmemeliyiz." ${ }^{84}$ İşte bu nedenle, Habermas'ın Derrida için, "Tanrının olmadığını bilir, ama yine de Ona inanmayı sürdürür" 85 demesi anlamlıdır. Dolayısıyla dinsel geleneklere karşı mesafeli durmak ve hatta onları ekarte etmek ve bununla birlikte aşkın Tanrıyı öldürmek ve yaratılmışla yaratan arasındaki sınırı kaldırmak suretiyle Tanrıyı içkinleştirmek postmodenistlerin genel tavrı olmuştur.

Zaten postmodernistler, geleneksel dinlere olan mesafelerini korumak için ironik bir biçimde 'dinselin geri dönüşü'nden bahsederler. Dinsel olanın geri dönüşüyle kastedilen, bildiğimiz dinlerin geri dönüşü değildir. Nitekim Vattimo, metafizik üst anlatıların yıkılmasıyla felsefenin dinin kabul edilebilirliğini keşfettiğini söyleyerek, dinsel olanın geri dönüşünü, olasıllk ve özgürlüğün bütün çizgilerini taşıyan, yoruma sonsuzca imkan tanıyan bir tarihsellik ufkunda kalmak olarak, yani Tanrının cisimleşmesi olarak yorumlar. ${ }^{86}$ Bir başka deyişle, Vattimo, Hıristiyanlığın özünü, enkarnasyonla birlikte Tanrının sahip olduğu her şeyi, tüm ötekiliğini, erkini ve otoritesini insanlara devrederek kendisini yoksunlaştırması ve insanın tek yasa olarak sevgiyi düşünmesi ve kabul etmesi biçiminde yorumlar. ${ }^{87}$ Yine Derrida, "İnanç, her zaman dinle ya da, bambaşka bir şeyle, teolojiyle bir tutulmamıştır, tutulmayacaktır da. Her türlü kutsallık ve her tür azizlik, terimin dar anlamıla, eğer

84 Alan de Botton, Ateistler İçin Din, çev. Ayşe Ece, Sel Yayıncllık, İstanbul 2011, s. 14.

85 Jurgen Habermas, İnsan Doğasının Geleceği, çev. Kaan H. Ökten, Everest Yayınları, İstanbul 2003, s. 173.

86 Gianni Vattimo, “İzin İzi”, Din, s. 82-83, 89

87 Richard Rorty, "Dinsel Zümre Karşıtlığı ve Ateizm", Dinin Geleceği, Santiago Zabala (der.), çev. Rahmi G. Öğdül, Ayrıntı Yayınları, İstanbul 2009, s. 39, 44 
öyle bir anlam varsa, dinsel olmak zorunda değildir. Artık Hıristiyan ya da İbrani örnekleriyle kısıtlı kalmayacak bir dini nasıl düşünmeli? İman Tanrı inancına doğru yönelmediği gibi, din de zorunlu olarak imanın hareketini izliyor değildir." 88 diyerek, dinselliği ya da imanı, sorumluluk, verilen söze inanma, karar ve güvende temellendirmiştir. Sorumluluk ve karar ancak ötekinin mevcudiyetiyle imkan alanına giren bir şeydir. Öteki, sonsuz sorumluluğumuzun kökenidir. Beni tam dilemmaya sürükleyen, doğrunun ve yanlışın ne olduğu konusunda bütünüyle belirsiz bir ufka batıran, kısaca tam bir belirsizliğin ve karar verilemezliğin içine düşüren bir durumda sorumluluk başlar. Öteki, bizi radikal belirsizliğin ve karar verilemezin içine düşüren, çatışan iki emrin muhatabı kılan ve böylelikle bizi tam bir karar verme gücüyle, özgürlük ve sorumlulukla donatandır. ${ }^{89}$ Dolayısıyla "din, cevabın [sorumluluğun] kendisidir. Gerçekten de sorumluluk ilkesi olmadan hiçbir cevap yoktur: ötekine, öteki ve kendi önünde cevap vermek gerekir." ${ }^{\prime 90} \mathrm{Ve}$ biz ötekine, bir iman edimi, yani iman düzeninde gerçekleşen bir "inan bana", güven bana" çağrısı olmaksızın hitap edemeyiz. Derrida'nın dini, açıkça görüleceği üzere, Kierkegaard ve Buber'in insani varoluşun sonsuz olanaklarının doruk noktası, karar verme, sorumluluk, kendilik ve özgürlügün en büyük imkanı olarak, Mutlak Öteki/Ezeli Sen/Nesnel Belirsiz/Saçma/Ezeli Dost/Aşkın Tanrı ile karşılaşmada temellendirdikleri dinin, aşkın Tanrısı atılmış ve sekülerleştirilmiş bir versiyonudur.

Özetle, postmodernistler için makbul din, Tanrısız bir dindir ya da sekülerleştirilmiş bir dindir. İçkinleştirilmiş ve hayatı yorumlamanın ve kimliklenmenin olumsal malzemelerinden biri olarak, dilin yarattığı ve hiçbir temeli, yaratıcılı̆̆ı, aşkınlığı, dışsal buyruğu ve otoritesi kalmamış; müphem, dünyevi, belirsiz, değişken ve muğlak karakterde, sonsuz yorumlama özgürlüğüyle sonsuzca çoğaltılabilen bir Tanrı ya da Tanrılar var artık karşımızda. Zaten postmodern birey, hiçbir geleneğe kendisini tam olarak ait hissetmeyen, belirsizlik, güvensizlik ve olumsallık içinde kendisini yapboz parçalarıyla sürekli yaratıp bozan biri değil miydi?

Postmodern evrende dinin varlığ 1 ve meşruiyetiyle ilgili olarak, hepimizin açıç̧a fark edeceği bir strateji uygulanıyor. Özgürlük ve

88 Jacques Derrida, “İnanç ve Bilim”, Din, s. 18, 22, 41

89 Jacques Derrida, "Yapıbozum ve Pragmatizm Üzerine Düşünceler", Yapıbozum ve Pragmatizm, s.136 vd.

90 Jacques Derrida, "İnanç ve Bilim", Din, s. 35 
farklılık adına bütün temeller yıkılıyor, evrenseller, mutlaklar, istikrarlı anlamlar, düzenlilikler, gerçeklikler, bütüncül tasarımlar vs. ayaklar altına alınıp eziliyor. Ne var ki insanoğlu belirsiz, rastlantısal ve olumsal bir evrende yaşama konusunda pek de yetenekli değil. Ayrıca bireylerin özgürlüklerinin ve farklılıkların korunması kolektif bir dayanışmayı ve birliği de zorunlu kılıyor. Birey-toplum ya da farklılık-birlik paradoksu terazisinin bir kefesi yükseltilirken diğer kefesi aşağıya kayıyor ve böylece denge bozulmuş oluyor. Oysa Derrida bize şunu açıkça göstermişti ki, biri olmadan diğeri var olamaz ya da bir şeyin imkanı, imkansızlığıdır. Bu durumda, birlik nasıl tesis edilecek acaba? Başarılması gereken, farklılıkta birlik paradoksunu hayata geçirebilmektir. İşte tam bu noktada, din değil ama dinsellik devreye sokuluyor. Bir başka ifadeyle, postmodernizm, özgürlük ve farklılık uğruna bütün temelleri, istikrarlı anlamları ve birlikleri yıkarken ve böylece toplumsallığın sonunu getirirken yine özgürlük ve farklılığı koruyan bir dayanışmanın ve birliğin de lüzumunu derinden hissetmekte ve bu yüzden dinselliğe müracaat etmektedir. Çünkü bireysel varoluşa ve farklılığa, bireyin kendisini belirleme ve kendi hayatına şekil verme özgürlügüne (herkes mutluluğu kendince arar, kimsenin kendi mutluluk anlayışını başkasına dikte etmeye hakkı yoktur) ve özerkliğe vurgu yapan postmodernizm bireyi güçlendirirken maneviyatı, dayanışmayı, kardeşliği, birlik ruhunu zayıflatmakta ve böylece bireyi yalnızlığa, toplumsal anomiye ve güvensizliğe mahkum etmektedir. Oysa hepimizin bildiği üzere, güçlü bir bireycilik durumunda toplumcuların/kollektivistlerin korkusu, değerlerde görelileşme ve dolayısıyla anarşi ve yönetimsizlik tehlikesidir. Bir kez toplum dağılmaya başlayınca ve yönetimsizlik tehlikesi baş gösterince, toplumu oluşturan bireylerin özgürlükleri ve en temel hakları tehlikeye girecektir. En azından birey, kendisinden daha güçlü gruplar ya da topluluklar karşısında kendi varlığını, kendi hak ve özgürlüklerini savunamayacak ve zayıf düşecektir. Dolayısıyla nihilizm, anarşi, kaos, güvensizlik, sosyal Darwinizm tehlikesi, organik bir dayanışma yoksunluğu vb. farklılaşmanın muhtemel risk ve tehditleridir her zaman.

Diğer yandan birliğe vurgu yapan dinsel, milliyetçi, sosyalist vb. akımlar ise bireyin özgürlügü, hakları ve özerkliği fikrini önemsizleştirmekte ve daha çok davanın bekasını sağlayacak değerler yaratmakta ve bu değerleri baskı ve güç yoluyla korumaya 
çalışmaktadır. Bu ikisi arasında denge yaratabilmek, bireyci anlayışa kolektif ruh, toplumcu anlayışa ise bireyci ruh aşılamakla mümkün gibi görünmektedir. Bir başka deyişle, mesele, "farklılık içinde birlik" yaratabilmektir. Touraine'in dediği gibi, demokrasi, "birlik ve çeşitliliğin, özgürlük ve bütünleşmenin uyuşma çabasıdır." ${ }^{\prime 11}$ Postmodernizm ise bu paradoksun imkanını dinde değil, dinsellikte arar. Sözgelimi Rorty, dinselliği, acıya karşı duyarlılık ve zulme karşı dayanışmadan hareketle gelecekte sevgi ve barışın tek yasa olacağ1 küresel bir uygarlıkta bulur92; Bauman, "dünveyi vecd"de ve insanların yapabildikleri ve kavrayabildikleri şeylerin sınırlarını sezmesinde dinselliği görür93; Vattimo dinselliği, Tanrının cisimleşmesi yoluyla insanın özgürleşmesinde, sonsuzca yorumlarla kendini geleceğin belirsiz ufkuna yöneltmesinde ve tek yasa olarak sevgiyi düşünmesinde bulur ${ }^{94} ;$ John D. Caputo için Tanrı, yeni bir doğumun, yeni bir başlangıcın, yeni bir beklentinin, geleceği dönüştürme umudunun adıdır. Onun gözünde dinsellik, insanın kendisini radikal bir belirsizliğe ve sonsuzca önü açık olan yaşama sunmasıdır. ${ }^{95}$ Derrida için ise dinsellik, öteki karşısındaki sonsuz sorumluluktur.

Ne var ki farklılıkta birliği tesis etmeye yönelen postmodern dinsellik, her ne kadar dinsel alandan ödünç alınmış gibi görünen ve anlamca benzeşen öteki, sevgi yasası, sonsuz sorumluluk, iyilikseverlik, adalet, güven, kendilik, zulme karşı koyma gibi kavramlar üzerinde önemle dursa da, bu kavramların aşkın ve nihai bir Tanrıyla olan bağını kesmiş ve sadece özneler arasında zuhur eden ve gerçeklik kazanan bir sevgi dini, adalet dini, ahlak dini, öteki dini kurmuştur. Artık bu kavramlar, Tanrı tarafından vahyedilen emirler olarak değil, sadece kişiler arası ilişkide, ötekiyle ilişkide gerçeklik ve anlam kazanan değerler olarak görülmektedir. ${ }^{96}$

Sonuç olarak, postmodern bir din, dilin yarattığı bir din olduğu için, eksiksiz, mutlak, evrensel ve nesnel anlamda kati bir hakikat görünümüne sahip olamaz. Dolayısıyla postmodern bir dinde ezeli

91 Alain Touraine, Demokrasi Nedir?, çev. Olcay Kunal, YKY, İstanbul 2011, s. 29.

92 Richard Rorty, "Dinsel Zümre Karşıtllğı ve Ateizm”, Dinin Geleceği, s. 44.

93 Zygmunt Bauman, Postmodernizm ve Hoşnutsuzlukları, s. 239.

94 Gianni Vattimo, "İzin İzi”, Din, s. 82-89; Richard Rorty, "Dinsel Zümre Karşıtllı̆̆1 ve Ateizm", Dinin Geleceği, s. 42.

95 Recep Alpyağıl, Derrida'dan Caputo'ya Dekonstrüksiyon ve Din, İz Yayıncllık, İstanbul 2007, s. 142-169.

96 John W. Murphy, Postmodern Sosyal Analiz ve Postmodern Eleştiri, çev. H. Arslan, Paradigma Yayınları, İstanbul 2000, s. 131. 
ve dil dışı hakikatlerden bahsetmek yersizdir. Din de tıpkı diğer metinler gibi sonsuz bireysel yoruma açıktır ve hiçbir din yorumu diğerine göre daha hakikatli, daha gerçek, daha doğru değildir. Bu yüzden burada söz konusu olan, evrensel ve mutlak bir din değil, bütünüyle göreli, müphem, değişken bir dindir. Tarihsel/kurumsal dinlerin varlığa tepeden/aşkın bir noktadan bakan ve her şeyi belirleyip açıklayan, her şeyi gözeten bir Tanrı ve vahiy merkezli, ezeli hakikatleri barındıran meta anlatısal yapısı, postmodern dinle birlikte kaybolmuştur ya da kaybolmadığı söylense bile böyle bir meta anlatıya karşı Lyotard'ın başlattığı savaş sürecektir. Dilin kendisi d1şında bir gerçekliğinin olmaması ve anlamın sonsuzca öznel yoruma açık olması, dahası anlam denen şeyin yazarın niyetinde değil metni okuyanın öznel yorumunda aranması sonsuz yoruma açık bir din mefhumunu gündeme getirir. Ancak çok daha önemli olan şey, insanın özgürlüğünü ve farklılığını korumak adına meta anlatısal bir yapıya ve tekçi, mutlak, evrensel bir hakikat çizgisine sahip her türden dinin, postmodern bir perspektifte reddediliyor oluşudur. $\mathrm{Bu}$, postmodernistlerin, insanı tektipleştiren ve tek bir hakikatin hizmetçisi kılan, insanın kendiliğindenliğini öldüren, karar verilemez durumlarda karar verebilme özgürlügüüü elinden alan güvenceli ve garantili bir hakikatler manzumesine mesafeli durmalarının bir neticesidir. İnsanın kendi varoluşunun sorumluluğunu kendi üzerine alabilmesi, kendi kararlarıyla kendini ve kendi değerlerini inşa edebilmesi için her şeyi bilen, her şeyi belirleyen, her şeyi gözetleyen ve ölüm sonrası sonsuzluk vaat eden imtiyazlı bir Tanrının öldürülmesi elzemdir. Din insanın kişisel ahlaki ve manevi gelişimine katkı yapması, sevgi, barış ve adaletin gerçekleşebilmesi, insanın kendi varlığını bir sanat eseri olarak işlemesi, yaratması, geliştirmesi ve varoluşunu gerçekleştirmesi ve ötekine, bütün insanlara karşı sonsuz sorumluluğu yüklenmesiyle vardır postmodernist düşünürlerde. Bir diğer deyişle, dinin ve Tanrının yerini kendilik kayg1sı, ahlaki ve siyasi idealler ve sorumluluk, duyum ve haz artırımı almıştır.

Peki geleneksel monoteistik dinlerin mensupları, yaratıcı ve aşkın bir Tanrıya inanan müminler için, modern-postmodern hesaplaşmasından çıkarmamız gereken dersler var mıdır? Öncelikle din, modern ya da postmodern olmak zorunda değildir. Bir başka ifadeyle, din, varlığın sürdürebilmek için modern ya da postmodern olana eklemlenmek ve bunlardan birinin diline indirgenmek zo- 
runda değildir. Din, kendine özgüdür. Onun kendine özgü bir ontolojisi, epistemolojisi, etiği vb. vardır. Onun dünyayı, varoluşu ve hayatı anlamlandırma ve yorumlama açısından kendine özgü bir dili, üslubu ve tarzı vardır. Wittgenstein'ın sözleriyle “Bir Tanrıya inanmak, yaşamın anlamını soran soruyu anlamak demektir. Bir Tanrıya inanmak, dünya olguları hakkında henüz son sözün söylenmediğini görmek demektir. Tanrıya inanmak, yaşamın bir anlamı olduğunu görmek demektir." ${ }^{97}$ Şimdiye kadarki izahlarımızdan açıça anlaşılacağı üzere, modernizm de postmodernizm de dinin kendine özgü anlamlandırma ve yorumlama tarzı ve tekniği üzerine inşa edilmiştir. Aydınlanma ve Modernizmin dinin tahtına oturarak varlığını kazandığı ve sürdürdüğünü yeterli açılıkla izah ettiğimiz kanaatindeyiz. Ancak postmodernizmin dayandığı ve beslendiği mistik/tasavvufi dayanak ve kökleri yeterince ortaya koymadık. Bu konu, elinizdeki yazımızın maksadını ve makul olması gereken hacmini aşacağı için, başka bir çalışmaya bırakılmıştır. Yine de, Nietzsche'nin Dionysos'unun, Heidegger'in Varlık ve hiçlik'inin, Derrida'nın karar verilemez ve ötekisinin ve içkinleştirilmiş bir Tanrı anlayışının, evrensel bir sevgi, hoşgörü, merhametin mistik/tasavvufi metinlere gönderme yapmadan layıkıyla anlaşılacağı kanaatinde değiliz. Hepimiz biliyoruz ki, vahdeti vücut demek, postmodernistlerin hep peşinde oldukları bir paradoks olan, "farklılıkta birlik" demektir.

Bununla birlikte, modernizm özerklik adına, postmodernizm ise olumsal özgürlük ve farklılık adına aşkın Tanrıyı öldürmek ve dinin metafizik temellerini yıkmak zorunda kalmıştır. İlle de Tanrıyı öldürmek ve metafizik temelleri yıkmak gerekmiyor bizim açımizdan. Ancak her iki söylemin de dine yönelik eleştirisini ciddiye almak ve şu dersi çıkarmak zorundayız: Din kendine özgü bir dil oyunu olma vasfını kaybetmeden ve metafizik temellerini yitirmeden özgürlüğü ve farklılığı tesis etmeye, bu dünyayı ve insanları ötekileştirmeden ve değersizleştirmeden bizlere sevdirmeye, sahici bir hoşgörüyü, merhameti, adaleti ve yaratıcllığı inşa etmeye mecburdur. Aksi halde hep ötekileştirmeyle, şiddetle, köleleştirmeyle, gayri insanilikle vs. anılacak ve insanlığın hafızasında ve yaşamında zamanla değerini ve önemini kaybedecek, nefretin, parçalamanın, istismar ve köleliğin arkaik bir simgesi durumuna dönüşecektir. Böyle bir akıbetten salim olabilmek ise, biz Müslümanların tek bir

97 Ludwig Wittgenstein, "Günlükler”, Felsefe ve Dil, Ömer Naci Soykan, s. 319. 
okuma ve tek bir yorumu dayatmaktan vazgeçip yorum farklılıklarını tanımasına ve özellikle bir zamanlar sürülen, işkence edilen, dışlanan ve öldürülen, farklılığın ve özgürlüğün simgesi Müslüman düşünürlere, filozoflara ve sufilere, ellerinden alınan itibarlarını geri vermesine ve onlarla barışmasına bağlıdır. Hatta kanaatimiz o dur ki, İslam'ın farklılık, çoğulculuk, özgürlük, sevgi ve hoşgörüyü tesis eden, besleyen ve teşvik eden biricik yüzü, sufilerin hayatı ve eserleridir. Çünkü onlar, bütün farklılıkları kucaklayan, tüm farklı dinleri hoş gören, Hakkın (Mutlak Ötekinin) hiçbir zaman kavranamayacağını ve kimsenin tekelinde olamayacağını dile getiren, ilahi ve evrensel bir aşkın sözcüleridirler.

Bugün hala Müslüman sufi ve filozoflarla ve tabi ki insanlığa ait bütün felsefelerle, bilimlerle, sanatlarla vb. barışmamakta diretiyorsak bu, farklılık ve özgürlük fikrine ne kadar uzak olduğumuzun ve tarih boyunca birlik, bütünleşme, bir dava potasında erime duygusunun genlerimize ne denli köklü ve sağlam kazındığının bir göstergesidir. Belki de savaşların acımasızlığı ve hayatta kalma mücadelesi bizleri hep bir olmaya itti ve birlik olmanın ne denli önemli olduğuna bizleri ikna etti. Ancak bu duygu nedeniyle yeniliğin ve yaratıcılığın yollarını tıkadığımızın, bir zamanlar felsefe, bilim ve tasavvufla edindiğimiz tüm kazanımlarımızı kaybettiğimizin, ancak Batıya eklemlenerek ve Batının himayesinde varlığımızı sürdürdüğ̈̈müzün farkına varmamız gerekiyor. Acilen farklılığın mühim bir değer olduğuna, eleştiri ve özgürlüğün hayati derecede önemli olduğuna, bu dünyanın güzel ve yaşanılası olduğuna ve dolayısıyla bu dünyayı ve hayatı okumanın, araştırmanın; sırf dinsel bir okuma değil tüm farklılıklara açık bir okuma ve araştırmanın ne denli kıymetli olduğuna bizi ikna edecek İslami argümanlara ve söylemlere ihtiyacımız var. Çünkü böylesi bir argüman ve söylemden hala yoksunuz. Yoksa dünya realitesi ve siyaseti bizi farklılıkları ve özgürlükleri tanımaya mecbur bırakacak ve sonunda hazırlıksız yakalandığımız bir ayrışma, farklılaşma ve özgürleşme hareketinin bir daha toparlanamayacak derecede altında ezilip kalacağız. En azından, farklılığı, özgürlüğü, yeniliği, yaratıcılığı körükleyen ve böylelikle diğer devletleri dize getirmek için güçlü devletleri ve doğaya egemen olabilmek için bilimleri yaratan Batı karşısında güçlü olmak zorundayız. Bu nedenle de öbür dünyaya dönük ekonomik ve mekanik okumaların dozunu azaltıp farklılıklara açık olmayı ve eleştirilerle kendimizi geliştirmeyi adet edinmemiz gerekiyor. William Barrett'in çok güzel ifade ettiği üzere, "Batılı 
düşünce mevcut çıkmazını aşacaksa bunu pekala Doğululaşma ile yapabilir; fakat bunun sonuçları Doğunun bildiği her şeyden çok farklı olacaktır." 98 Aynı şekilde, Doğulu düşünce de mevcut çıkmazlarını aşmayı istiyorsa, bunu ancak Batılılaşma yoluyla gerçekleştirebilir; fakat bunun sonuçları Batının bildiği her şeyden çok farklı olacaktır.

\section{Kaynakça}

Alpyağıl, Recep, Derrida'dan Caputo'ya Dekonstrüksiyon ve Din, İz Yayınc1lık, İstanbul 2007

Aristoteles, Felsefeye Çağrı: Protreptikos, çev. S. Ö. Akkaş, Doruk Yayınları, Ankara 1999

Bakunin, Mihail, Tanrı ve Devlet, çev. Mustafa Tüzel, Belge Yayınları, İstanbul 2013

Barrett, William, İrasyonel İnsan, çev. Salih Özer, Hece Yayınları, Ankara 2003.

Baudrillard, Jean, Anahtar Sözcükler, çev. O. Adanır ve L. Yıldırım, Paragraf Yayınları, Ankara 2005

Simülakrlar ve Simülasyon, çev. Oğuz Adanır, Doğubatı Yayınları, Ankara 2008

Bauman, Zygmunt, Siyaset Arayışı, çev. Tuncay Birkan, Metis Yayınları, İstanbul 2000

Modernlik ve Müphemlik, çev. İsmail Türkmen, Ayrıntı Yayınları, İstanbul 2003

Postmodernlik ve Hoşnutsuzlukları, çev. İsmail Türkmen, Ayrıntı Yayınları, İstanbul 2000

Berten, Andre, Pablo da Silveira ve Pourtois, Herve (Der.), Liberaller ve Cemaatçiler, çev. B. Demir, M. Develioğlu, Dost Yayınları, Ankara 2006

Best, Steven ve Kellner, Douglas, Postmodern Teori, çev. Mehmet Küçük, Ayrıntı Yayınları, İstanbul 1998

Botton, Alan de, Ateistler İçin Din, çev. Ayşe Ece, Sel Yayıncılık, İstanbul 2011

Connolly, William E., Kimlik ve Farklılık, çev. Ferma Lekesizalın, Ayrıntı Yayınları, İstanbul 1995

Deleuze, Gilles, Müzakereler, çev. İnci Uysal, Norgunk Yayıncılık, İstanbul 2006

Derrida, J., Kermode, F., Moi, T., Norris, C., Teoriden Sonra Hayat, M. Payne ve J. Schad (der.), çev. Ebru Kılıç, Agora Kitaplığı, İstanbul 2004

Derrida, J., Vattimo, G., Din, çev. D. Kundakçı ve M. E. Özcan, Dost Kitabevi Yayınları, Ankara 2011

98 William Barrett, İrrasyonel İnsan, çev. Salih Özer, Hece Yayınları, Ankara 2003, s. 236. 
Postmodernizm ve Tanrı'nın Ölümü: Öznenin Arkeolojisi Üzerine Bir Deneme

Derrida, Jacques, "Yapıbozum ve Pragmatizm Üzerine Düşünceler", Yaptbozum ve Pragmatizm, C. Mouffe (der.), çev. Tuncay Birkan, Sarmal Yayınevi, İstanbul 1998

Gramatoloji, çev. İsmet Birkan, Bilgesu Yayıncılık, Ankara 2010

Eagleton, Terry, Postmodernizmin Yanılsamaları, çev. Mehmet Küçük, Ayrıntı Yayınları, İstanbul 1999

Eagleton, Terry, Kuramdan Sonra, çev. Uygar Abacı, Literatür Yayınları, İstanbul 2006

Foucault, Michel, Özne ve İktidar, çev. I. Ergüden ve O. Akınhay, Ayrıntı Yayınları, İstanbul 2005

Habermas, Jurgen, İnsan Doğasının Geleceği, çev. Kaan H. Ökten, Everest Yayınları, İstanbul 2003

Herakleitos, Kırık Taşlar, Çev. Alova, Bordo-Siyah Yayınları, İstanbul 2003

Horkheimer, Max, Akıl Tutulması, çev. Orhan Koçak, Metis Yayınları, İstanbul 1994

Horkheimer M. ve Adorno, T. W., Aydınlanmanın Diyalektiği I, çev. Oğuz Özügül, Kabalcı Yayınları, İstanbul 1995,

Kierkegaard, Soren, Günlüklerden ve Makalelerden Seçmeler, çev. İ. Kapakl1kaya, Anka Yayınları, İstanbul 2005

Leibniz, G. W., Monadoloji, çev. Suut K. Yetkin, MEB Yayınları, İstanbul 1997 Metafizik Üzerine Konuşma, çev. A. Timuçin, Cumhuriyet Dünya Klasikleri, Ankara 1999

Lyotard, Jean-François, Postmodern Durum, çev. Ahmet Çiğdem, Ara Yayınc1lik, İstanbul 1990

Murphy, John W., Postmodern Sosyal Analiz ve Postmodern Eleştiri, çev. H. Arslan, Paradigma Yayınları, İstanbul 2000

Nietzsche, F., İyinin ve Kötünün Ötesinde, çev. Ahmet İnam, Say Yayınları, İstanbul 2009

Ahlakın Soykütü̈̆̈̈, çev. Ahmet İnam, Yorum Yayınevi, İstanbul 2001

Deccal: Hıristiyanlığa Lanet, çev. Oruç Aruoba, Hil Yayınları, İstanbul 1995 Şen Bilim, çev. Levent Özşar, Asa Yayınları, Bursa 2003 Güç İstenci, çev. Sedat Umran, Birey Yayıncılık, İstanbul 2002

Platon, Theaitetos, çev. M. Gökberk, MEB Yayınları, İstanbul 1997

Popper, Karl, Açık Toplum ve Düşmanları, Cilt II, çev. Harun Rızatepe, Liberte Yayınları, Ankara 2008

Rorty, Richard, Olumsallık, İroni ve Dayanışma, çev. M. Küçük ve A. Türker, Ayrıntı Yayınları, İstanbul 1995

Rorty, Richard, “Dinsel Zümre Karşıtlı̆̆ı ve Ateizm”, Dinin Geleceği, Santiago Zabala (der.), çev. Rahmi G. Öğdül, Ayrıntı Yayınları, İstanbul 2009 
Rosenau, Pauline Marie, Post-Modernizm ve Toplum Bilimleri, çev. Tuncay Birkan, Bilim ve Sanat Yayınları, Ankara 2004

Russell, Bertrand, Sorgulayan Denemeler, çev. N. Arık, Tübitak Yayınları, Ankara 1998

Sarup, Madan, Post-Yapısalcılık ve Postmodernizm, çev. Abdülbaki Güçlü, Bilim ve Sanat Yayınları, Ankara 2004

Smart, Barry, "Postmodern Toplum Teorisi", Modernite versus Postmodernite, Mehmet Küçük (der.), Vadi Yayınları, Ankara 2000

Spinoza, B., Törebilim, çev. A. Yardımlı, İdea Yayınları, İstanbul 2000

Touraine, Alain, Demokrasi Nedir?, çev. Olcay Kunal, YKY, İstanbul 2011

Trigg, Roger, Reason and Commitment, Cambridge University Press, 1973

Wagner, Peter, Modernliğin Sosyolojisi, çev. Mehmet Küçük, Ayrıntı Yayınları, İstanbul 2005

Wittgenstein, Ludwig, Tractatus Logico-Philosophicus, çev. Oruç Aruoba, YKY, İstanbul 2001 "Günlükler", Felsefe ve Dil: Wittgenstein Üstüne Bir Araştırma, (Ömer Naci Soykan), Kabalcı Yayınevi, İstanbul 1995. "Notlar", Felsefe ve Dil: Wittgenstein Üstüne Bir Araştırma, (Ömer Naci Soykan), Kabalcı Yayınevi, İstanbul 1995.

Yeğenoğlu, M. ve Mutman, M., "Bilimlerde ve Toplumda Postmodernizm”, Birikim, Sayı: 33, 1992. 


\title{
MİLEL VE NiHAL
}

inanç, kültür ve mitoloji araştırmaları dergisi

Cilt/Volume: 12 Sayı/Number: 2 Temmuz - Aralık / July - December 2015 ISSN: $1304-5482$

Bu dergi uluslararası EBSCO HOST Research Databases veri indeksi ve TÜBITAK-ULAKBİM Sosyal ve Beşeri Bilimler Veri Tabanı tarafından taranmaktadır.

\section{Sahibi / Owner}

Milel ve Nihal Eğitim, Kültür ve Düşünce Platformu Derneği adına Şinasi Gündüz

\author{
Yazı İşleri Sorumlusu / Legal Representative \\ Yasin Aktay
}

Editör / Editor

Şinasi Gündüz

Editör Yrd. / Co-Editor

Cengiz Batuk

Hakan Olgun

\section{Sayı Editörü / Editor of Issue \\ Mustafa Tekin}

Yayın Kurulu/ Editorial Board*

Alpaslan Açıkgenç, Ayaz Akkoyun, Yasin Aktay, Mahmut Aydın,

Cengiz Batuk, Şinasi Gündüz, İbrahim Kayan, Hakan Olgun, Necdet Subaşı,

Burhanettin Tatar

\section{Danışma Kurulu/Advisory Board*}

Baki Adam (Prof. Dr., AÜ); Mohd. Mumtaz Ali (Prof. International Islamic U. Malezya); Adnan Aslan (Prof.Dr., Süleyman Şah Ü.); Kemal Ataman (Doç.Dr., Uludağ Ü.); Mehmet Akif Aydın (Prof. Dr., Marmara Ü.); Yılmaz Can (Prof. Dr., OMÜ); Ahmet Çakır (Doç. Dr., OMÜ); Mehmet Çelik

(Prof. Dr., Celal Bayar Ü.); Waleck S. Dalpour (Prof. University of Maine at Farmington); İsmail

Engin (Dr., Berlin); Cemalettin Erdemci (Prof.Dr. YYÜ); Tahsin Görgün (Prof.Dr., 29

Mayıs Ü.) Ahmet Güç (Prof.Dr., Uludağ Ü.); Recep Gün (Doç. Dr., OMÜ); Ö. Faruk Harman

(Prof.Dr., Mar.Ü.); Erica C.D. Hunter (Dr., Cambridge U.); Mehmet Katar (Prof. Dr., A.Ü.);

Mahmut Kaya (Prof. Dr., İ.Ü.); Sadık Kılıç (Prof.Dr., Atatürk Ü.); Şevket Kotan (Y.Doç.Dr., İ.Ü.);

İlhan Kutluer (Prof.Dr., Mar. Ü.); George F. McLean (Prof. Catholic Univ., Washington DC); Ahmet Yaşar Ocak (Prof. Dr., Hacettepe Ü.); Jon Oplinger (Prof. University of Maine at Farmington); Ömer

Özsoy (Prof.Dr., Frankfurt U.); Roselie Helena de Souza Pereira (Mestre em

Filofia-USP; UNICAMP Brasil); Ekrem Sarıkçıŏlu (Prof.Dr., SDÜ); Hüseyin Sarığlu (Prof.Dr.,

İ̈); Bobby S. Sayyid (Dr. Leeds U.); Mustafa Sinanoğlu (Prof.Dr., 29 Mayıs Ü.); Mahfuz Söylemez

(Prof.Dr. İ̈); Necdet Subaşı (Y.Doç.Dr., DİB); Bülent Şenay (Prof.Dr., UÜ); İsmail Taşpınar

(Prof.Dr. Mar.Ü.); C. Sadık Yaran (Prof.Dr., OMÜ); Ali Murat Yel (Prof.Dr., Fatih Ü.); Hüseyin Yılmaz (Doç.Dr., YYÜ); Ali İhsan Yitik (Prof. Dr., DEÜ)

* Soyadına göre alfabetik sıra / In alphabetical order

Kapak ve Sayfa Tasarımı / Cover \& Page Design İnan Avc1

Baskı / Publication

Ladin Ofset - İstanbul, Nisan 2016

2.Mat. Sit. 3 NB 15 Topkapı İstanbul / İsmail Tüz 02125012418

Yönetim Yeri / Administration Place

Milel ve Nihal Eğitim, Kültür ve Düşünce Platformu Derneği

Fevzipaşa Cad. Şehit Mehmet Sarper Alus Sok. No: 5, K.: 3, Tel: (0212) 5339731 Fatih/İstanbul www.milelvenihal.org e-posta: dergi@milelvenihal.org

Milel ve Nihal yılda iki sayı olarak altı ayda bir yayımlanan uluslararası hakemli bir dergidir. Milel ve Nihal'de yayımlanan yazıların bilimsel ve hukuki sorumluluğu yazarlarına aittir. Yayım dili Türkçe ve İngilizce'dir. Yayımlanan yazıların bütün yayın hakları Milel ve Nihal'e ait olup, yayıncının izni olmadan kısmen veya tamamen basılamaz, çoğaltılamaz ve elektronik ortama taşınamaz. Yazıların yayımlanıp yayımlanmamasından yayın kurulu sorumludur. 


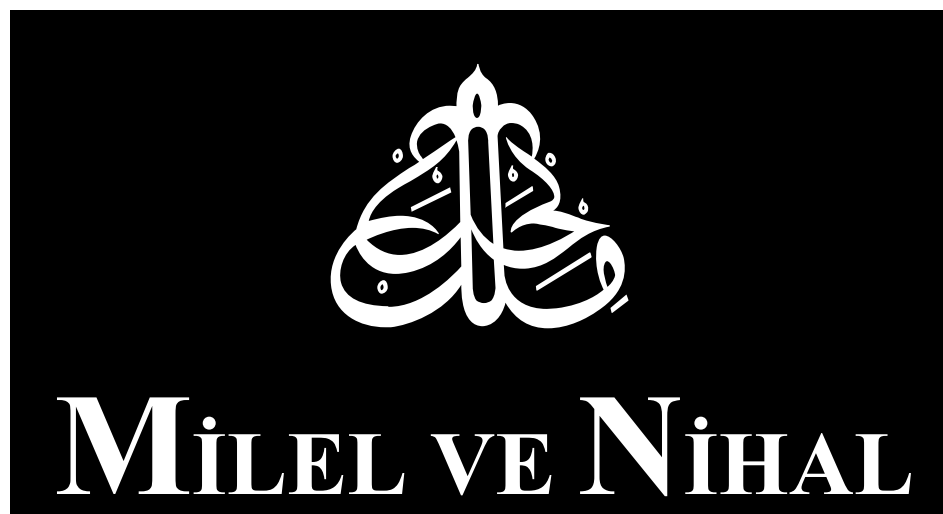

inanç, kültür ve mitoloji araştırmaları derģisi

ISSN: 1304-5482

DIN VE POSTMODERNIZMM

Cilt/Volume: 12 Sayı/Number: 2

Temmuz - Aralık / July - December 2015 
